\title{
The Use of Interactions Between Microorganisms in Strawberry Cultivation (Fragaria $x$ ananassa Duch.)
}

\author{
Magdalena Drobek ${ }^{1}$, Justyna Cybulska ${ }^{1 *}$, Anna Gałazka², Beata Feledyn-Szewczyk ${ }^{2}$, \\ Anna Marzec-Grzadziel'2, Lidia Sas-Paszt ${ }^{3}$, Agata Gryta1 , Paweł Trzciński ${ }^{3}$, \\ Artur Zdunek ${ }^{1}$ and Magdalena Frac ${ }^{1}$ \\ ${ }^{1}$ Institute of Agrophysics, Polish Academy of Sciences, Lublin, Poland, ${ }^{2}$ The Institute of Soil Science and Plant Cultivation \\ (IUNG)-State Research Institute, Puławy, Poland, ${ }^{3}$ National Institute of Horticultural Research, Skierniewice, Poland
}

As the market indicates a growing interest in organically grown fruit, there is a need for biostimulants to counter the adverse effects of pathogenic fungi and fungal-likepathogens. Four microbial pathogens (Botrytis cinerea, Verticillium sp., Phytophthora sp., and Colletotrichum sp.) which are the most often causes of strawberry diseases were selected. Five kinds of biostimulants (C1, C2, C3, C4, and C5) containing bacterial consortia were developed to combat the pathogens. The antagonistic effect of selected microorganisms against strawberry pathogens was observed. The effectiveness of various beneficial bacteria in combating fungal pathogens of cv. Honeoye strawberries was compared and the impact of their activity on fruit quality was assessed. The most significant effect on the strawberry firmness was found for the $\mathrm{C} 2$ consortium, which provided the strawberries infected with the pathogens group (MIX: B. cinerea, Verticillium sp., Phytophthora sp., and Colletotrichum sp.) with a $140 \%$ increase in maximum load in a puncture test compared to the positive control (C0). Strawberries contaminated with Phytophthora sp. after the application of Consortium C4 (C4) showed the largest increase (127\%) in soluble solid content (SSC) when compared to the C0. Fruit contaminated with Colletotrichum sp. and B. cinerea after the application of C2 and Consortium 5 (C5), respectively, had the highest levels of anthocyanins and total phenolic content, when compared to $\mathrm{CO}$. The largest increase, which reached as high as 25\%, in D-galacturonic acid content was observed for the group of pathogens after Consortium 1 (C1) application. The extraction of strawberry pectin allowed for the study of the rheological properties of pectin solutions; on this basis, strawberry pectin from the control (NC) was distinguished as it showed the highest viscosity (0.137-0.415 Pas). Taking into account the individual effects of bacteria on strawberry pathogenic fungi and fungal-like-pathogens, it is possible to reduce the adverse effects of fungal disease and to improve the properties of strawberries by selecting the appropriate bacterial consortium. Interactions between microorganisms are often complex and not fully understood, which suggests the need for further research in this direction. 


\section{INTRODUCTION}

The strawberry is one of the most frequently preferred fruit by consumers due to availability year around and suitable for both organic and conventional production (Balci, 2021; Juric et al., 2021). Excessive pesticide use in conventional crops may lead to their accumulation in the fruit. For this reason, alternative control measures, which include the biopesticides or antagonistic microorganisms (Jensen et al., 2013). The organic farming system differs from the conventional one in prohibition of synthetic plant protection products (pesticides) and mineral fertilizers. The chemical plant protection products are replaced with organic fertilizers, which contain, among others, manure, compost, green manure, beneficial microorganisms (Ponder and Hallmann, 2019). In the context of organic fertilizers, the concept of biostimulants appears. Biostimulants are defined by the European Biostimulants Industry Council as "substance (s) and/or microorganisms whose function, when applied to plants or the rhizosphere, is to stimulate natural processes to increase/benefit nutrient uptake, nutrient efficiency, tolerance to abiotic stress, and quality of the crops "(European Biostimulants Industry Council [EBIC], 2021). It has been proven that biostimulants increase plant yield and improve fruit quality. Additionally, consumers are more interested in ecological products each year, bearing in mind the safety of food and the environment (Kovačević et al., 2015).

The microbiota present on healthy strawberries is complex and includes potential plant pathogens, human pathogens, mycotoxin-producing moulds and plant disease biocontrol agents (Jensen et al., 2013). Some of these microorganisms are antagonistic to the others. Notable bacterial antagonism against pathogenic fungi occurs with considerable frequency and is the result, among other causes, of the production of antibiotics and biosurfactants, as well as competition and parasitism (Berg et al., 2000). The mechanisms of action differ depending on the bacterial strain. The most common strawberry pathogens include fungi from the genera Botrytis, Verticillium, Phytophthora, Colletotrichum, Penicillium, Alternaria, Cladosporium, Rhizopus, Aureobasidium, and Cryptococcus (Tournas and Katsoudas, 2005). Bacterial populations on strawberry plants are dominated by Pseudomonas spp., Stenotrophomonas spp., Bacillus spp., and Arthrobacter spp. (Krimm et al., 2005).

One of the main strawberry postharvest diseases is grey mould which is caused by Botrytis cinerea. A grey coating appears on the leaves and fruit causing the plants to die off and the fruit to dry and rot (Jin et al., 2017). Research results suggest that the following microorganisms are active in combating grey rot: Clonostachys rosea (Cota et al., 2009), Rhodotorula glutinis (Srivastava et al., 2011), Paenibacillus polymyxa (Santiago et al., 2016), Bacillus sp. (Cruz et al., 2018), Streptomyces sp. (Kim et al., 2015), and Pseudomonas sp. (Haggag and Abo El Soud, 2012). The withering of strawberry plants is mainly caused by Verticillium dahliae, which attacks the plant's vascular system and blocks the transport of water and nutrients (Sowik et al., 2001). Research indicates that $P$. polymyxa (Zhang et al., 2018), Bacillus sp. (Milijasevic-Marcic et al., 2018), and Streptomyces sp. (Olanrewaju and Babalola, 2019) are disease-inhibiting bacteria. Fungus-like pathogens of the genus Phytophthora including Phytophthora megasperma, Phytophthora cryptogea, Phytophthora capsici, Phytophthora Citricola, and Phytophthora cactorum can cause diseases of the root, crown and strawberry fruit. Infected plants suddenly lose healthy shoots. A relatively rare disease is red stele in strawberries (Phytophthora fragariae). Infected plants become stunted and the leaves turn yellow or red (Wilcox et al., 1993). Streptomyces griseus has shown promising results as an antifungal agent against $P$. capsici, as it produces numerous antibiotics that inhibit mycelium growth of P. capsici, Pythium spp., Phytophthora spp., Rhizoctonia solani, Alternaria brassicicola, and Botrytis sp. (Nguyen et al., 2015). The fungi belonging to the species of Colletotrichum asianum, Colletotrichum fructicola, Colletotrichum tropicale, Colletotrichum dianesei, Colletotrichum karstii (Lima et al., 2013), Colletotrichum gloeosporioides (Tang et al., 2019), and Colletotrichum acutatum (Moreira et al., 2014) cause anthracnose of fruit, which in the case of strawberries is manifested by the appearance of dry spots on immature fruit, and the browning and drying of flowers and shoots (Lima et al., 2013). It has been shown that the fungi Aureobasidium pullulans, Diaporthe sp., and Nigrospora oryzae inhibits the development of C. acutatum (Landum et al., 2016). Useful fungi and bacteria limit the growth and development of pathogens by activating antagonistic mechanisms such as parasitism, antibiotics, and competition (Poveda et al., 2020).

We investigated the impact of various biostimulants containing fungi and bacteria on the quality characteristics of strawberry fruit infected with microbial pathogens. The experiment included four fungal pathogens responsible for the most common strawberry diseases. Bacterial consortia with potentially antagonistic effects were applied to the infected plants infected with B. cinerea, Verticillium sp., Phytophthora sp., and Colletotrichum sp. The results allow for a preliminary selection of microorganisms that can be used to combat strawberry fungal diseases.

\section{MATERIALS AND METHODS}

\section{Crop Conditions}

The experiment was set up in triplicate for each of the 36 variants (Figure 1) and the research material consisted of strawberry cv. Honeoye. Each strawberry plant was grown in a separate pot without undercutting or root curling in a greenhouse at $23^{\circ} \mathrm{C}$. Each pot contained $4 \mathrm{~kg}$ of soil collected from an organic experimental field of the Institute of Soil Science and Plant Cultivation - State Research Institute (Puławy, Poland) located in Grabów (Poland) and it was subjected to chemical and microbiological analysis. The soil was characterized as Cambisol with a loamy sand texture. Clover was used as a pre-crop. The soil composition was as follows: humus $1.9 \%, \mathrm{P}_{2} \mathrm{O}_{5} 10.1 \mathrm{mg} 100 \mathrm{~g}^{-1}$ soil, $\mathrm{K}_{2} \mathrm{O} 5.0 \mathrm{mg} 100 \mathrm{~g}^{-1}$ soil, $\mathrm{Mg} 10.6 \mathrm{mg} 100 \mathrm{~g}^{-1}$ soil, $\mathrm{N}-\mathrm{NO}_{3}$ $8.92 \mathrm{mg} \mathrm{kg}^{-1} \mathrm{DM}$ of soil, N-NH $42.29 \mathrm{mg} \mathrm{kg}^{-1} \mathrm{DM}$ of soil, $\mathrm{pH}$ 5.9. Keramzite was placed at the bottom of each pot in a volume of $0.5 \mathrm{l}$. The soil was fertilized in autumn with manure $\left(\mathrm{pH}=8.6\right.$, nutrient content: $\mathrm{N} 5.06 \mathrm{mg} \mathrm{kg}^{-1}, \mathrm{P}_{2} \mathrm{O}_{5} 2.47 \mathrm{mg}$ 
$\mathrm{kg}^{-1}, \mathrm{~K}_{2} \mathrm{O} 6.90 \mathrm{mg} \mathrm{kg}^{-1}, \mathrm{CaO} 3.04 \mathrm{mg} \mathrm{kg}^{-1}, \mathrm{MgO}^{2.38} \mathrm{mg} \mathrm{kg}^{-1}$, $\mathrm{S} 0.69 \mathrm{mg} \mathrm{kg}^{-1}$ ) and potassium salt (LUVENA, $100 \mathrm{~kg} \mathrm{ha}^{-1}$ ). Bioilsa ${ }^{\circledR}$ (NaturalCrop, Poland) fertilizer was applied in a quantity corresponding to a dose of $150 \mathrm{~kg} \mathrm{ha}^{-1}$.

Plants were treated with five consortia (C1, C2, C3, C4, and $\mathrm{C5}$ ) and a control (C0) was prepared, in which no consortia were applied (Figure 1). The consortia consisted of the following bacterial strains: AF117AB (P. polymyxa), Sp115AD (Bacillus subtilis), AF75AB2, Sp115AD, AF75BC (Bacillus sp.), AF75AA, AF75AD (Streptomyces sp.), JAFGU (Lysobacter sp.), and AF70AC (Pseudomonas sp.). The bacterial strains used in the experiment originated from the SYMBIOBANK collection of the Research Institute of Horticulture in Skierniewice and were selected based on a previous study as microorganisms with potentially beneficial properties in terms of plant biostimulation and protection. The bacterial consortia, with a population size of $10^{8} \mathrm{cfu}$ (colony-forming units) in $1 \mathrm{ml}$, were applied to the soil in a volume of $10 \mathrm{ml}$ per pot directly to the roots at planting time and twice after planting at intervals of 3-4 weeks. The objects called "Consortium C0," in which bacteria were not introduced, were the control for the ones containing bacterial consortia with their potential for plant biostimulation and protection, while NC objects constituted controls without pathogen contamination.

The next step was the infection of plants with five phytopathogenic fungi and fungus-like pathogens (BC, V, P, C, and MIX) and the submission of the control (NC) in which the plants were not treated with pathogens (Figure 1). Two days after plant inoculation with bacterial consortia, the plants were infected with the following pathogens: G277/18 (Botrytis cinerea), G296/18 (Verticillium sp.), G408/18 (Phytophthora sp.), G171/18 (Colletotrichum sp.). Strains of B. cinerea, Phytophthora sp., and Verticillium sp. were isolated from infected strawberry roots (Oszust et al., 2020), while Colletotrichum sp. was isolated from infected strawberry fruit (Malarczyk et al., 2020) at the Institute of Agrophysics of the Polish Academy of Sciences (Lublin, Poland). In the case of $B$. cinerea and Colletotrichum sp. the strawberry flowers were infected with $10 \mathrm{ml}$ of pathogen suspension using an inoculum adjusted to 1,000 conidia in $1 \mathrm{ml}$. In contrast, Phytophthora sp. and Verticillium sp. were added to the soil as a pathogen inoculum suspension of $10^{5} \mathrm{cfu} \mathrm{m}^{-1}(10 \mathrm{ml}$ was applied) and $10^{4} \mathrm{cfu} \mathrm{g}^{-1}$ of soil, respectively.

At the harvest maturity stage, the strawberries (developed and grown, and the sepals easily detach from the stalk) were collected on March 23, 2019.

\section{Firmness}

Firmness is one of main parameter of texture which determine overall quality evaluation by consumers (Harker et al., 2003). For soft fruit puncture test is the most common method used for determination of firmness (Døving and Måge, 2002). Fresh fruit firmness (n) was determined by a puncture test by using a universal test machine (Lloyd LRX, Lloyd Instruments). The strawberry was placed on the platform of the device and the aluminium probe ( $3 \mathrm{~mm}$ diameter) was lowered with a constant plunger speed $\left(20 \mathrm{~mm} \mathrm{~min}^{-1}\right)$ to a constant depth $(6 \mathrm{~mm})$. The maximum force required to penetrate the strawberry to a set depth was a measure of tissue firmness (Fraeye et al., 2009). The test was carried out on twenty strawberries for each replicate of the variant. Average fruit firmness was expressed in terms of $N$.

\section{Shape}

The shape of the fruit is a hormone-regulated trait and many factors can alter the final shape including environmental conditions (Rey-Serra et al., 2021). The shape was determined in accordance with the method proposed by Ishikawa et al. (2018). The length (the longer dimension was measured from the fruit's tip to the base) and width (the shorter dimension of the fruit, was measured as a transverse measurement at the thickest point) of the fruit were determined. The quotient of length and width was calculated. Fruits are classified as flattened (quotient $<1$ ), round (quotient $=1$ ), or oblong (quotient $>1$ ). The test was carried out on fifteen strawberries for each replicate of the variant.

\section{Fresh Weight of Fruit}

Fresh weight is the weight of the fruit on the day it is harvested. It is determined by a weight method to initially determine the size of the fruit (Reyes-Yanes et al., 2020). The purpose of determining the fresh weight is to obtain information on the effectiveness of the cultivation methods. Comparison the fresh weight, dry weight and shape provides information on the hydration level of the fruit and the tissue density (Miller et al., 2000). To determine the fresh weight of fruit (FWF), each fruit was weighed to three decimal places. The results were summed and averaged. The average fresh fruit weight was expressed in $\mathrm{g}$.

\section{Dry Weight of Fruit}

The dry matter allows the determination of the product residue after the removal of water from it (Ozdemir and Topuz, 2004). The drying oven method is a validated standardized method that is readily available (International Organization for Standardization, 2000). Dry weight (DW) was determined according to the procedure described in standard PN ISO 1026:2000 (International Organization for Standardization, 2000). In Brief, $0.5 \mathrm{~g}$ of strawberries were taken from each variant in triplicate and weighed to the nearest $0.001 \mathrm{~g}$. The strawberries were then placed in an oven at $105^{\circ} \mathrm{C}$, after $24 \mathrm{~h}$ the fruit was weighed, placed in the oven for $2 \mathrm{~h}$ and weighed again. The procedure was repeated until no further weight loss was noted. The average dry weight of one fruit was expressed as a percentage of fresh weight.

\section{Soluble Sugar Content}

The soluble solid content (SSC) is a measure of the total soluble solid, which includes sugars, organic acids, amino acids, and more, and it is associated with consumer preference for fruit (Crisosto et al., 2003). The refractometric method is used because of the optical properties of sugars and sugar alcohols which are majority of soluble solids of most fruit (Magwaza and Opara, 2015). SSC was determined using a refractometer (PAL-BX/RI, ATAGO, Japan) and expressed in percentage terms. A minimum of five fresh strawberries were picked and juiced. One drop of juice was applied to the refractometer glass and the measurement 


\begin{tabular}{|c|c|c|}
\hline $\begin{array}{c}\text { Consortium C0 } \\
\text { Soil with manure }+ \text { medium } \\
+ \text { Bioisla }\end{array}$ & $\begin{array}{c}\text { Consortium C1 } \\
\text { AF117AB (Peanibacillus polym } \\
\text { Sp115AD (Bacillus subtilis) }\end{array}$ & $\begin{array}{l}\text { Consortium C2 } \\
\text { AF75AB2 (Bacillus sp.), } \\
\text { Sp115AD (Bacillus sp.), } \\
\text { AF75BC (Bacillus sp.) }\end{array}$ \\
\hline $\begin{array}{c}\text { NC } \\
\text { control } \\
\text { (no contamination) }\end{array}$ & $\begin{array}{c}\text { NC } \\
\text { control } \\
\text { (no contamination) }\end{array}$ & $\begin{array}{c}\text { NC } \\
\text { control } \\
\text { (no contamination) }\end{array}$ \\
\hline $\begin{array}{c}\text { BC } \\
\text { Botrytis cinerea }\end{array}$ & $\begin{array}{c}\mathbf{B C} \\
\text { Botrytis cinerea }\end{array}$ & $\begin{array}{c}\text { BC } \\
\text { Botrytis cinerea }\end{array}$ \\
\hline$\frac{\mathbf{V}}{\text { Verticillium } \mathrm{sp} .}$ & $\begin{array}{c}\mathbf{V} \\
\text { Verticillium sp. }\end{array}$ & $\begin{array}{c}\mathbf{V} \\
\text { Verticillium sp. }\end{array}$ \\
\hline $\begin{array}{c}\mathbf{P} \\
\text { Phytophthora sp. }\end{array}$ & $\begin{array}{c}\mathbf{P} \\
\text { Phytophthora sp. }\end{array}$ & $\begin{array}{c}\mathbf{P} \\
\text { Phytophthora sp. }\end{array}$ \\
\hline $\begin{array}{c}\text { C } \\
\text { Colletotrichum sp. }\end{array}$ & $\begin{array}{c}\text { C } \\
\text { Colletotrichum sp. }\end{array}$ & $\begin{array}{c}\text { C } \\
\text { Colletotrichum sp. }\end{array}$ \\
\hline $\begin{array}{c}\text { MIX } \\
\text { pathogen group } \\
(\mathrm{BC}, \mathrm{V}, \mathrm{P}, \mathrm{C})\end{array}$ & $\begin{array}{c}\text { MIX } \\
\text { pathogen group } \\
(\mathrm{BC}, \mathrm{V}, \mathrm{P}, \mathrm{C})\end{array}$ & $\begin{array}{c}\text { MIX } \\
\text { pathogen group } \\
(\mathrm{BC}, \mathrm{V}, \mathrm{P}, \mathrm{C})\end{array}$ \\
\hline $\begin{array}{c}\text { Consortium C3 } \\
\text { AF75AA (Streptomyces sp.), } \\
\text { AF75AD (Streptomyces sp.) }\end{array}$ & $\begin{array}{c}\text { Consortium C4 } \\
\text { JAFGU (Lysobacter sp.), } \\
\text { C10C09 (Pseudomonas sp.), } \\
\text { AF70AC (Pseudomonas sp.) }\end{array}$ & $\begin{array}{c}\text { Consortium C5 } \\
(\mathrm{C} 1+\mathrm{C} 2+\mathrm{C} 3+\mathrm{C} 4)\end{array}$ \\
\hline $\begin{array}{c}\text { NC } \\
\text { control } \\
\text { (no contamination) }\end{array}$ & $\begin{array}{c}\text { NC } \\
\text { control } \\
\text { (no contamination) }\end{array}$ & $\begin{array}{c}\mathbf{N C} \\
\text { control } \\
\text { (no contamination) }\end{array}$ \\
\hline $\begin{array}{c}\text { BC } \\
\text { Botrytis cinerea }\end{array}$ & $\begin{array}{c}\text { BC } \\
\text { Botrytis cinerea }\end{array}$ & $\begin{array}{c}\text { BC } \\
\text { Botrytis cinerea }\end{array}$ \\
\hline $\begin{array}{c}\mathbf{V} \\
\text { Verticillium sp. }\end{array}$ & $\begin{array}{c}\mathbf{V} \\
\text { Verticillium sp. }\end{array}$ & $\begin{array}{c}\mathbf{V} \\
\text { Verticillium sp. }\end{array}$ \\
\hline $\begin{array}{c}\mathbf{P} \\
\text { Phytophthora sp. }\end{array}$ & $\begin{array}{c}\mathbf{P} \\
\text { Phytophthora sp. }\end{array}$ & $\begin{array}{c}\text { P } \\
\text { Phytophthora sp. }\end{array}$ \\
\hline $\begin{array}{c}\text { C } \\
\text { Colletotrichum sp. }\end{array}$ & $\begin{array}{c}\text { C } \\
\text { Colletotrichum sp. }\end{array}$ & $\begin{array}{c}\text { C } \\
\text { Colletotrichum sp. }\end{array}$ \\
\hline $\begin{array}{l}\text { MIX } \\
\text { pathogen group } \\
(\mathrm{BC}, \mathrm{V}, \mathrm{P}, \mathrm{C})\end{array}$ & $\begin{array}{c}\text { MIX } \\
\text { pathogen group } \\
(\mathrm{BC}, \mathrm{V}, \mathrm{P}, \mathrm{C})\end{array}$ & $\begin{array}{c}\text { MIX } \\
\text { pathogen group } \\
(\mathrm{BC}, \mathrm{V}, \mathrm{P}, \mathrm{C})\end{array}$ \\
\hline
\end{tabular}


was performed; the soluble sugar content was expressed in percentage terms. The measurement was performed in triplicate for each variant of the experiment.

\section{Total Phenolic Content}

Due to the strong antioxidant activity of most phenolic compounds in fruits, the total polyphenol content is determined for the evaluation of health-promoting properties. The FolinCiocalteu method has been used for many years and is still relevant today due to its high accuracy (Carmona-Hernandez et al., 2021). Phenolic compounds (PC) were determined according to the procedure proposed by Folin and Ciocalteu (1927) and Nunes et al. (2001), with some modifications. From each variant of the experiment, five fruit were taken in triplicate and then juiced. Then, $0.5 \mathrm{ml}$ of the clear juice was diluted by adding $9.5 \mathrm{ml}$ of deionized water. The resulting solution was spiked with $5 \mathrm{ml}$ of Folin-Ciocalteu reagent (1:9 dilution) and $4 \mathrm{ml}$ of sodium carbonate $\left(0.075 \mathrm{~g} \mathrm{ml}^{-1}\right)$. The mixture was left to stand for $30 \mathrm{~min}$ at $30^{\circ} \mathrm{C}$, and then transferred to an ice bath $\left(0^{\circ} \mathrm{C}\right)$ for $30 \mathrm{~min}$. The absorbance of the solutions was measured at $760 \mathrm{~nm}$. The content of phenolic compounds was determined using gallic acid solution as a standard, and the phenol concentration was expressed in $\mathrm{mg} 100 \mathrm{~g}^{-1} \mathrm{FW}$.

\section{Anthocyanins Content}

Anthocyanin is natural dye responsible for the color of the fruit and belongs to antioxidants which demonstrate health beneficial properties. The spectrophotometric method based on the reversible discoloration of anthocyanin depending on the $\mathrm{pH}$ is commonly used to measure the anthocyanin content (Johnson et al., 2020). The anthocyanins content (AC) was determined according to a previous procedure described by Nunes et al. (2001) and consisted of measuring the content of pelargonidin-3glucoside [the main pigment in strawberries (Nunes et al., 2001)]. For each variant, $2 \mathrm{~g}$ of strawberry pulp was collected in triplicate. Subsequently, $18 \mathrm{ml}$ of $0.5 \%(\mathrm{v} / \mathrm{v}) \mathrm{HCl}$ in methanol was added to the pulp and the mixture was incubated in a refrigerator $\left(4^{\circ} \mathrm{C}\right)$ for $1 \mathrm{~h}$ to extract the pigment. After incubation, the mixture was centrifuged and the supernatant was used to determine the anthocyanin content through the use of spectrophotometry at $520 \mathrm{~nm}$. The anthocyanin content was calculated using the following formula: $A_{520} *$ dilution factor ${ }^{*}$ [molecular weight of pelargonidin-3-glucoside (PGN)/molar extinction coefficient $(\mathrm{MEC})]$, where $\mathrm{PGN}=433.2, \mathrm{MEC}=2.908^{*} 10^{4}$. The result was expressed in terms of an average of three repetitions in terms of mg $100 \mathrm{~g}^{-1} \mathrm{FW}$.

\section{Pectin Extraction}

Pectin are one of the basic components of the cell wall. It has been shown that oxalate-soluble pectin play a significant role in shaping the texture of the fruit, which directly affects, among others, resistance to mechanical damage (Makarova and Shakhmatov, 2020). Strawberry pectin analysis was carried out according to the procedure proposed by Koubala et al. (2008) and Min et al. (2011) with some modifications. $1 \mathrm{~g}$ of pulp was taken in triplicate from each experimental variant. $35 \mathrm{ml}$ of $0.25 \%$ ammonium oxalate $(\mathrm{pH}=4.6)$ was added to the pulp and the mixture was transferred to a water bath $\left(85^{\circ} \mathrm{C}\right)$ for $1 \mathrm{~h}$. After incubation, the mixture was centrifuged $(20,000 \times \mathrm{g})$ for $10 \mathrm{~min}$ and the supernatant was collected. Three volumes of $96 \%$ ethanol were added to the supernatant and the solution was incubated in a refrigerator $\left(4^{\circ} \mathrm{C}\right)$ for $24 \mathrm{~h}$. The next step was to centrifuge $(20,000 \times g, 10 \mathrm{~min})$ the solution and discard the supernatant. The remaining residue contained pectin, it was washed twice with $96 \%$ ethanol, dried and used to determine the D-galacturonic acid content.

\section{Galacturonic Acid Content}

Content of galacturonic acid as the main component of pectin determines suitability of fruit for processing (gelling, production of ascorbic acid) (Ben Abdallah et al., 2018). The content of Dgalacturonic acid (GalA) in strawberries was determined using a continuous flow analyser (CFA), SanPlus (Skalar, Netherlands) according to the procedure recommended by the manufacturer. The applied automatic colorimetric method of measurement of GalA content is based on a color reaction, where the color intensity is measured at a wavelength of $520 \mathrm{~nm}$ (Ognyanov et al., 2021). $10 \mathrm{mg}$ of dried pectin was dissolved in $12 \mathrm{ml}$ of deionised water. The resulting solution was diluted 10 times and the Dgalacturonic acid content was determined. The result is expressed in $\mathrm{g} \mathrm{kg}^{-1} \mathrm{DW}$.

\section{Rheological Properties}

The rheological properties, which demonstrate the relationship between the structural, mechanical and sensory properties, are among the basic parameters of pectin (Xie et al., 2021). The rheological properties were measured using a Discovery HR-1 hybrid rheometer (TA Instruments, United States) with a coneplate sensor. In brief, $1 \%$ aqueous solutions of strawberry pectin extracted with ammonium oxalate were prepared according to a procedure described elsewhere (Koubala et al., 2008; Min et al., 2011). For each variant of the experiment, pectin solutions were prepared in triplicate and each measurement was carried out at a temperature of $20 \pm 0.5^{\circ} \mathrm{C}$. Viscosity was measured at a constant shear rate of $10 \mathrm{~s}^{-1}$ (three repetitions), and the flow curves were determined based on measurements at variable shear rates of 10 and $600 \mathrm{~s}^{-1}$. Flow curves were described using the Ostwald-de Waele model as represented by the following equation:

$$
\sigma=k \gamma^{\mathrm{n}}
$$

where $\sigma$ is shear stress $(\mathrm{Pa}), k$ is consistency index $\left(\operatorname{Pas}^{\mathrm{n}}\right), \gamma$ is shear rate $\left(\mathrm{s}^{-1}\right)$ and $\mathrm{n}$ is flow behaviour index.

\section{Antagonistic Properties of Consortia Against Fungal Pathogens}

Antagonistic properties of consortia against fungal pathogens are determined in order to test the effectiveness of the tested bacterial consortia in combating fungal and fungal-like pathogens in the strawberry (Win et al., 2021). In vitro confrontations of four separate bacterial consortia and their mixtures (C5) against four selected phytopathogenic fungi and fungal-like-pathogens were set up using the plate culture method (Petri dish diameter $90 \mathrm{~mm}$ ) with potato dextrose agar (PDA). Paper discs (5 mm diameter) 
were surface sterilized with UV light, dipped in $30 \mu \mathrm{l}$ of bacterial consortia suspension $\left(10^{8} \mathrm{cfu} \mathrm{m}^{-1}\right)$ and placed in duplicates on Petri dishes inoculated with fungal pathogens. The pathogen inoculation included $150 \mu \mathrm{l}$ of inoculum of a 7-day old culture of B. cinerea G277/18, Phytophthora sp. G408/18, Verticillium sp. G296/18, and Colletotrichum sp. G171/18 suspended with $10 \mathrm{ml}$ of sterile water. The concentration of $B$. cinerea and

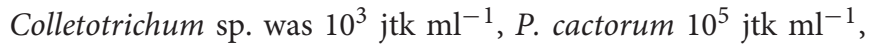
and Verticillium sp. $10^{4} \mathrm{jtk}^{-1}$. The pathogen-inoculated plates with discs soaked in bacterial consortia were incubated at $26^{\circ} \mathrm{C}$ in the dark. The observations were recorded 4 days after inoculation by measuring the fungal growth inhibition zone around the paper discs containing bacterial consortia.

\section{Characteristics of Soil Used for Strawberry Cultivation}

Characteristics of soil used for strawberry cultivation is a source of information about the processes during the growth and development of plants, which can have a direct impact on the quality of the fruit. Methods determining the content of proteins, enzymes, carbon and nitrogen in soil provide information on the level of soil degradation and allow the assessment of the importance of the biological consortia used (Wang et al., 2017). Soil samples were taken by complete randomization from a depth of $0-15 \mathrm{~cm}$. The soil was dried at $23^{\circ} \mathrm{C}$ and sieved through a sieve with a mesh diameter of $2 \mathrm{~mm}$. Total glomalin content (TG), easily extractable fractions of glomalin (EEG) (Wrigth and Upadhyaya, 1998), soil enzyme activity (dehydrogenase DHA) (Klein et al., 1964), acidic phosphatase (ACP), alkaline phosphatase (ALP) (Tabatabai and Bremner, 1969), as well as the carbon and nitrogen content in the biomass were determined in the samples.

\section{Principal Component Analysis}

Principal component analysis (PCA) is used to discover regularities between variables. It consists in determining the components which are a linear combination of the examined variables. PCA enables the identification of those initial variables that have a significant impact on the appearance of individual principal components (Yagmur and Gunes, 2021). In order to assess the relationship between the studied parameters, PCA analysis was performed using STATISTICA software (Statistica v.12, StatSoft Inc., United States).

\section{Statistical Analysis}

The obtained results were analysed with STATISTICA software (Statistica v.12, StatSoft Inc., United States) using a two-way analysis of variance (ANOVA) followed by the Tukey HSD test or Tuckey for different N, F-Welch and RIR Tuckey test for unequal numbers or ANOVA Kruskal-Wallis test; significant differences were determined at $P<0.05$.

\section{RESULTS AND DISCUSSION}

Strawberries are in high demand because of their taste and health-promoting properties resulting from the presence of antioxidants and vitamins. The development of organic farming and the promotion of a healthy lifestyle has significantly increased the demand for organically grown fruit. The recent guidelines of the European Green Deal and Biodiversity Strategy have led to the use of sustainable practices, such as organic farming, and to a reduction in the use of chemical pesticides (European Commission, 2019). These measures have led to fruit producers ensuring the high quality of their strawberries by using natural plant protection preparations. For this purpose, plant extracts, microbial consortia that antagonize strawberry pathogens (Ornelas-Paz et al., 2013) and plant protective hormones (Poveda, 2020) are both desirable and beneficial in terms of biocontrol. For economic reasons, it is important that ecological preparations not only increase the quality of the fruit, but also guarantee a plentiful harvest, reasonable production costs and that the market price of the fruit should be taken into consideration. Therefore, bacterial strains with potentially antagonistic properties against main fungal and fungal-like pathogens were selected for this study.

\section{Strawberry Quality}

The shape of strawberries has a significant influence over visual quality and consumer interest. Based on previous findings, auxin derived from achene is responsible for cell division and expansion (Zahedipour-Sheshglani and Asghari, 2020), this changes the shape of the strawberry. Consumers prefer round strawberries (Zahedipour-Sheshglani and Asghari, 2020). The change in shape from oblong (in $\mathrm{C} 0$ ) to round after the use of the appropriate consortium was noted in strawberry $\mathrm{P}$ (C4 and C5) and (Figure 2D), which makes them the most attractive to the consumer. Strawberry V (C4), P (C3), and MIX (C2) were distinguished by their flattened shape (Figures 2C,D,F). The remaining fruits were characterized as oblong.

An important parameter for assessing the quality of strawberries is firmness. Ensuring the proper firmness of the fruit allows for longer storage periods and facilitates transport over greater distances (Liu et al., 2019). The highest increase in firmness was observed for MIX-infected strawberries treated with $\mathrm{C} 2$, the maximum load in this case was on average 2.4 times higher than in the control (C0) (Figure 2F). A statistically significant increase in the maximum load value as compared to the control was also observed in the $\mathrm{NC}(\mathrm{C} 1), \mathrm{P}(\mathrm{C} 4)$, and $\mathrm{C}$ (C5) groups (Figures $\mathbf{2 A}, \mathbf{D}, \mathbf{E}$ ). It is assumed that the reason for the increase in the firmness of strawberries infected with selected pathogens could be the activity of bacterial consortia associated with the production of metabolites limiting mycelium growth and leading to an improvement in the quality and firmness of the fruit. Strawberries soften during ripening, mainly by degrading the middle lamina of the cell wall of the cortical parenchyma cells (Qin et al., 2017). One of the reasons for this degradation may be the activity of fungal pathogens attacking the fruit during ripening and storage (Ahmadi-Afzadi et al., 2013). The treatment of strawberries with Hanseniaspora uvarum yeast and infection with $B$. cinerea has been shown to preserve fruit firmness as compared to the control (Qin et al., 2017). The impact of the investigated bacterial consortia and fungal and fungal-like pathogens on the firmness of strawberries has not 


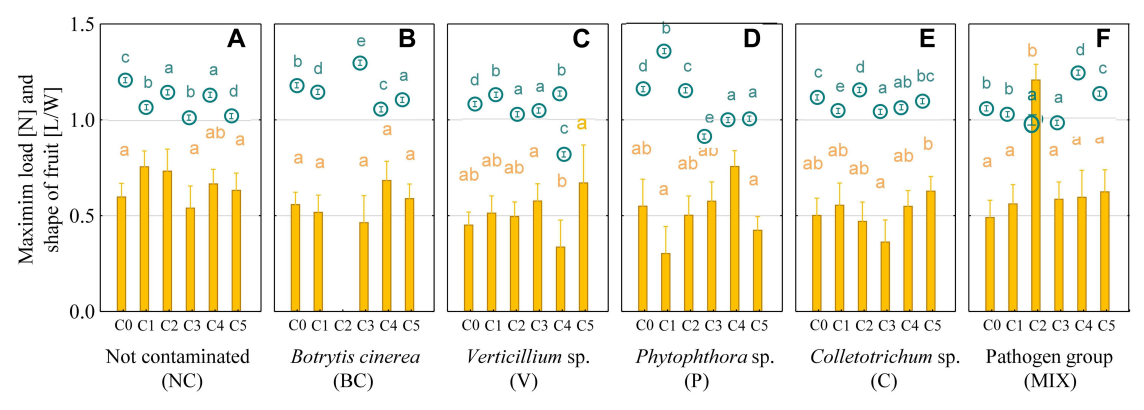

O. Shape

Maximum load
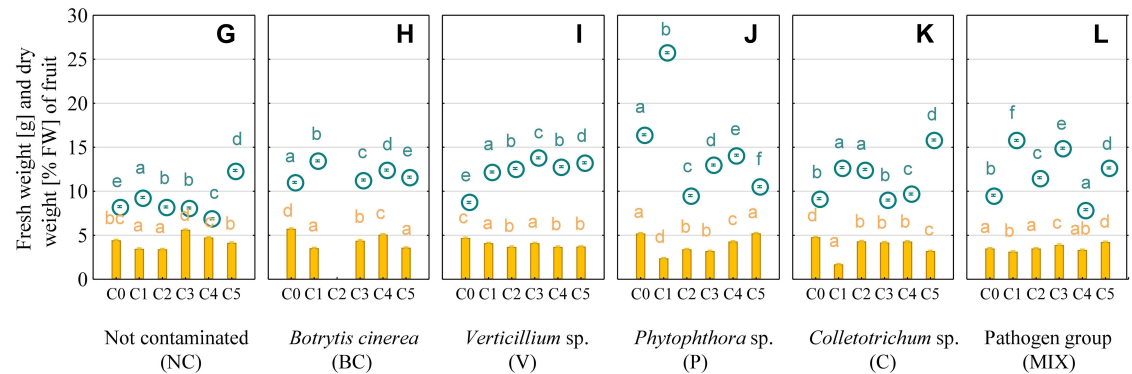

(C)

(MIX)

(1) Dry weight of fruit

Fresh weight of fruit
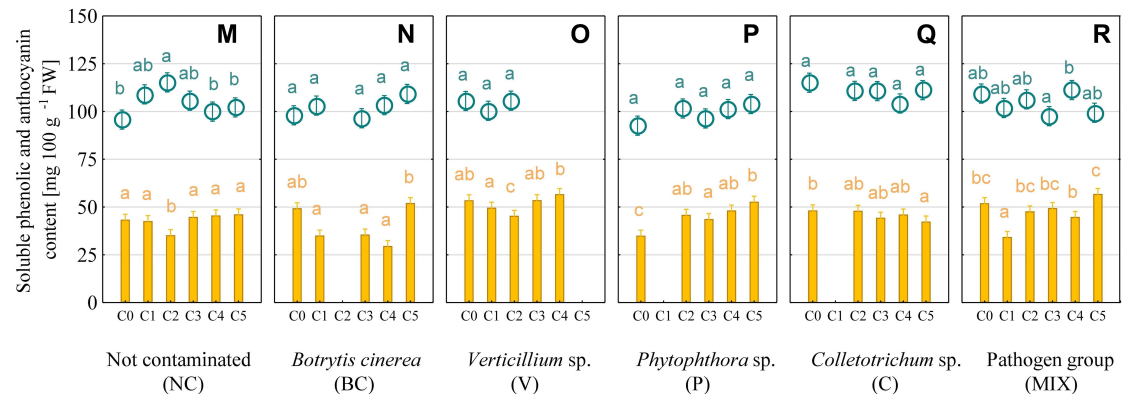

(NC)

(BC)

(V)

(P)

$\begin{array}{cc}\text { Colletotrichum sp. } & \text { Pathogen group } \\ \text { (C) } & \text { (MIX) }\end{array}$

(MIX)

(1) Soluble phenolic content

Anthocyanin content

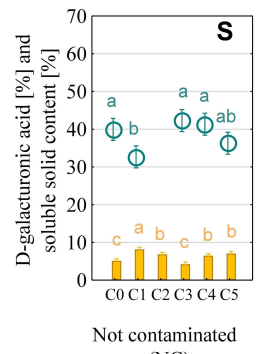

(NC)

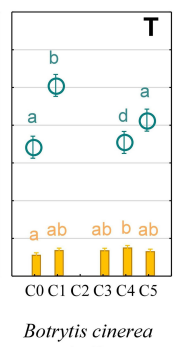

(BC)

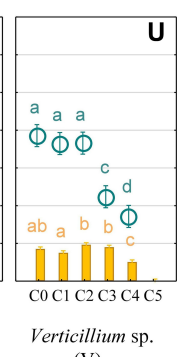

(V)

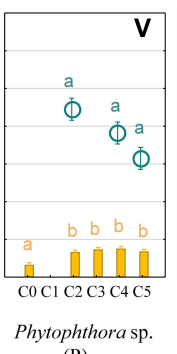

(P)

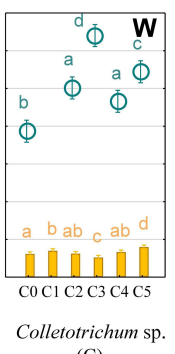

(C)

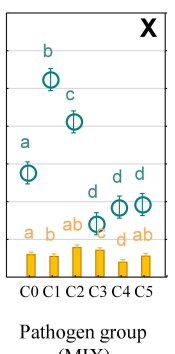

(MIX)

\section{(1) D-galacturonic acid content} Soluble solid content

FIGURE 2 | Firmness of strawberries and shape (A-F), fresh and dry weight (G-L), soluble phenolic and anthocyanin content (M-R), and D-galacturonic acid and soluble solid content (S-X) in strawberry fruit. C0, control (not contaminated); C1, Consortium 1; C2, Consortium 2; C3, Consortium 3; C4, Consortium 4; C5, Consortium 5. A statistical analysis was performed for each pathogen group of plants separately. The data are means \pm SD $(n>3)$. Different letters (a-f) indicate the differences between consortia $(P<0.05)$ as determined by the following statistical test: ANOVA Tuckey test for different $\mathrm{N}$ for maximum load (C-E) and shape (A-F); F-Welch test and RIR Tuckey test for unequal numbers for (A,B,F), ANOVA and Tuckey test HSD for fresh weight (G,H,L), dry weight (L), anthocyanin (N-Q), soluble phenolic (N-Q), D-galacturonic acid (W), soluble solid content (W,X); F-Welch and post hoc for fresh weight (I-K), dry weight (J,K), anthocyanin (M,R), soluble phenolic (M,R), D-galacturonic acid (S-U,X), soluble solid content (S-U); ANOVA Kruskal-Wallis test for dry weight (G-I), D-galacturonic acid (V), soluble solid content (V). 
yet been investigated. The production of various metabolites that dissolve mycelium might play a role (Olanrewaju and Babalola, 2019). It is known that treating strawberries with beneficial microorganisms can improve the quality and properties of the stored fruit, including firmness (Fan et al., 2009). The antifungal activity of Bacillus sp. isolates against C. acutatum (Moreira et al., 2014) and Phytophthora infestans (Caulier et al., 2018), Lysobacter sp. and Pseudomonas sp. against Colletotrichum sp. (Tang et al., 2019), S. griseus against P. capsici (Nguyen et al., 2015) and Lysobacter sp. against P. infestans (Lazazzara et al., 2017) have been confirmed.

Fruit firmness is closely related to the dry matter content. Their soft texture and high water content make strawberry fruit susceptible to mechanical and physical damage which facilitates the penetration of microorganisms (Siebeneichler et al., 2020). In General, fruit with a higher tissue density exhibits a higher dry matter content and a greater degree of firmness compared to fruit with a lower tissue density (Tarantino et al., 2018). This relationship was observed for the strawberries $\mathrm{NC}(\mathrm{C} 1)$ and C (C5), with an increase in firmness and dry matter compared to the control (Figures 2A,E, 3A,E). An inverse relationship was observed in samples P (C4) and MIX (C2), fruit with a higher degree of firmness had a lower or comparable to the control dry content (Figures 2D,F, 3D,F). It is assumed that the decrease in the firmness of fruit with a high dry matter content is caused by a relatively high cell fragility, low turgor pressure or a low degree of adhesion between the adjacent strawberry tissue cells (Harker et al., 2000).Tissue hydration has a great impact not only on firmness, but also on fresh fruit weight. Studies have shown that strawberries may contain $84-92 \%$ water, depending on the variety and cultivation method (Liu et al., 2019). Only the $\mathrm{C} 3$ bacterial consortium increased the fresh matter content over the no contaminated (NC) strawberry by 63\% (Figure 3G) and $\mathrm{C} 3$ and $\mathrm{C} 5$ consortia increased the fresh matter content in MIX-infected strawberry by $21 \%$ on average (Figure $3 \mathrm{~L}$ ). The higher fresh weight combined with the lower dry weight values indicate a higher water content in the strawberries belonging to these groups.

One of the factors determining consumer interest in strawberries is the SSC content, which is defined as the aggregate concentration of sugars ( $80-90 \%$ of the SSC), acids and other solutes in the cell juice (Mackenzie et al., 2011). The average content of SSC in the tested fruits was 6\% (Figures 2S-X), which is the same as other studies which reported the content of SSC in strawberries to be within the range of $4-10 \%$ (Chen H. et al., 2018). In most cases, the SSC content was greater than or comparable to the control (C0) in strawberries treated with the bacterial consortia. A statistically significant decrease in the SSC value by $0.9-3.4 \%$ compared to the control $(\mathrm{C} 0)$ was observed in groups V (C4), C (C3), and MIX (C1 and C4) (Figures $\mathbf{2} \mathbf{U}, \mathbf{W}, \mathbf{X}$ ). The occurrence of differences in the content of SSC in the tested strawberries is natural and may result from differences in the cultivation method (Cao et al., 2015) consisting of treating the fruit with different bacterial consortia. The SSC content is influenced by various factors, such as genetics, climate, water management and cultivation practices. Positive correlations between the nutrient content, e.g., phosphorus and an increase in SSC content was noted for the strawberries (Valentinuzzi et al., 2015). This effect may occur due to the ability of bacteria to dissolve phosphates, which lowers soil $\mathrm{pH}$ and increases phosphorus availability through the production of organic acids. Moreover, an increase in the content of phosphorus in the fruit was shown after the treatment of strawberry seedlings with Bacillus sp. and Klebsiella planticola (Tomic et al., 2015).

Polyphenols and anthocyanins are responsible for the bright red colour of strawberries and play a key role as bioactive ingredients (de Andrade et al., 2019). The mean content of polyphenols in the tested fruit was in the range of 93$115 \mathrm{mg} 100 \mathrm{~g}^{-1}$, while the anthocyanins content was in the range of $31-57 \mathrm{mg} 100 \mathrm{~g}^{-1}$. The increase in polyphenol content was only observed in the NC group (C2) and was $20 \%$ greater than in the control $(\mathrm{C} 0)$ (Figure $2 \mathrm{M}$ ). None of the preparations used caused a statistically significant decrease in the content of polyphenols in strawberry cv. Honeoye. Unlike the case of polyphenols, a decrease in the content of anthocyanins in strawberry NC (C2), V (C2), and MIX (C1) was noted (Figures $\mathbf{2 M}, \mathbf{O}, \mathbf{R}$ ). However, an increase in anthocyanin content at the level of $25-51 \%$ compared to the control (C0) occurred only in the group of Phytophthora sp. infected strawberries treated with C2, C3, C4, and C5 consortia (Figure 2P). It is predicted that the changes to the level of total phenolic compounds and anthocyanins may be due to the presence of pathogenic fungi, and fungal-likepathogens, and beneficial bacteria. The bacterial synthesis of plant hormones or amino acids may enter the shikimic acid metabolic pathway, thereby acting as the precursors of phenolic acids (Cisternas-Jamet et al., 2020). The increase in anthocyanin content may be attributed to the release of anthocyanins from degraded cellular components (López-Ortiz et al., 2019), the activity of the enzymes responsible for the synthesis of anthocyanins and also the activity of microorganisms. Lingua et al. (2013) demonstrated the positive effect of bacteria of the genus Pseudomonas on the anthocyanin (cyanidine-3-glucoside and pelargonidine-3-glucoside) concentration in strawberries. However, the anthocyanin content shows a high degree of variability with respect to species, varieties, growth conditions and the degree of fruit ripeness (Todeschini et al., 2018).

The content of galacturonic acid (Figure 2), which is the main component of pectin, is important in fruit processing. Pectins have stabilizing and gelling properties, which is why they are used in the production of jam, juice, drinks, and jellies (Ben Abdallah et al., 2018). In addition, galacturonic acid is extracted from fruit for the synthesis of ascorbic acid (Agius et al., 2003). The content of galacturonic acid may vary; in a previous study, a ripe strawberry of the cultivar Chandler was found to contain about $330 \mathrm{mg}$ of galacturonic acid g ${ }^{-1}$ DW (Paniagua et al., 2017). The use of consortia resulted in an increase in the galacturonic acid content of $\geq 400 \mathrm{mg} \mathrm{g}^{-1} \mathrm{DW}$ ( $>40 \%$ ) for strawberry grown in the following variants: $\mathrm{BC}(\mathrm{C} 1), \mathrm{C}(\mathrm{C} 2, \mathrm{C} 3, \mathrm{C} 4$, and $\mathrm{C} 5)$, and MIX ( $\mathrm{C} 1$ and $\mathrm{C} 2$ ) (Figures $2 \mathrm{~T}, \mathbf{W}, \mathbf{X}$ ), which was greater than the control (C0). Relatively large fluctuations in the content of galacturonic acid confirms the complexity of the processes caused by the activity of microorganisms, which are affected by 

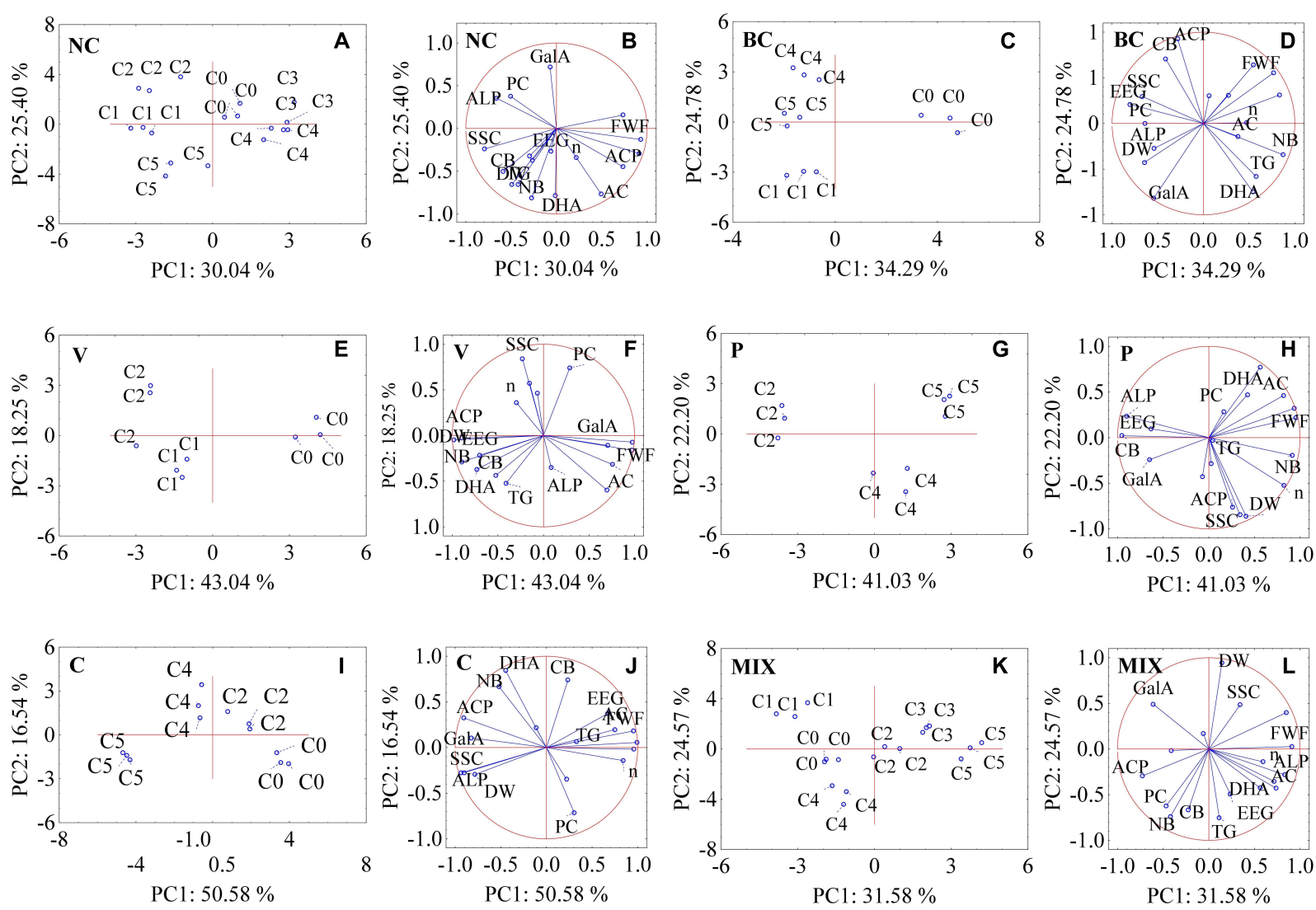

FIGURE 3 | Principal component analysis (PCA) showing interrelation of microbiological consortia used and quality parameters of strawberry fruit and soil. (A,B) NC (no contamination), (C,D) BC (B. cinerea), (E,F) V (Verticillium sp.), (G,H) P (Phytophthora sp.), (I,J) C (Colletotrichum sp.), (K,L) MIX (pathogen group: BC, V, P, C.); C0, control (no bacterial consortia); C1, Consortium 1; C2, Consortium 2; C3, Consortium 3; C4, Consortium 4; C5, Consortium 5; FWF, fresh weight of fruit; DW, dry weight of fruit; SSC, soluble solid content; PC, content of phenolic compounds; AC, content of anthocyanins; GalA, content of D-galacturonic acid; n, viscosity; TG, total glomalin; EEG, easily extractable glomalin; DHA, dehydrogenase activity; ACP, acid phosphatase activity; ALP, alkaline phosphatase activity; CB, carbon inbiomass; NB, nitrogen in biomass.

plant variety, growth conditions, pathogen infections and the consortia used.

\section{Rheological Properties}

The rheological properties of liquids determine the behaviour of the solution at all of the production stages, such as filling, mixing, packaging and removal from the package (Lee et al., 2009). Pectin solutions are used for the production of yoghurts, jelly, juices (Ke et al., 2020), paints, pastes and medicines (Jouini et al., 2018), due to their gelling, stabilizing and flavour-enhancing properties (Ke et al., 2020).

The viscosity of $1 \%$ solutions of strawberry pectin extracted with ammonium oxalate is shown in Table 1. The increase in viscosity as compared to the control (C0) occurred in NC (C3), $\mathrm{BC}(\mathrm{C} 1, \mathrm{C} 4$, and $\mathrm{C} 5), \mathrm{C}(\mathrm{C} 2)$, and $\operatorname{MIX}(\mathrm{C} 2, \mathrm{C} 3, \mathrm{C} 4$, and $\mathrm{C} 5)$ strawberries. Also, contamination with pathogens (BC, V, C, and MIX) significantly lowered the viscosity of the strawberry pectin solutions in the controls ( $\mathrm{C} 0$ ) as compared to the control of uninfected $\mathrm{NC}$ strawberries ( $\mathrm{C} 0)$. These results show that the use of appropriate consortia, dedicated to a specific pathogen, can increase the viscosity of pectin solutions. The decrease in viscosity may be attributed to the activity of microorganisms that soften the fruit cell walls though pectin degradation (Mierczyńska et al., 2014). Viscosity depends, among other factors, on the molecular weight of the pectin molecules, their degree of methylation and $\mathrm{pH}$, which may be affected by fungi and bacteria associated with strawberries at all stages of growth and ripening. It has been proven that viscosity increases with increasing pectin concentration (Chan et al., 2017).

The rheological data of the $1 \%$ pectin solutions were suitably adjusted by the Ostwald-de Waele model with a high coefficient of determination of $R^{2}>0.996$. Higher values of the coefficient $\mathrm{k}$ correspond to the higher viscosity of the samples. Based on the $k$-factor analysis, pectin solutions were obtained with a viscosity higher than that of the control (C0) in the $\mathrm{NC}(\mathrm{C} 3)$ and $\mathrm{BC}$ (C4 and C5) groups (Table 1). The antagonistic interactions of the microorganisms used led to the modification of pectin, an increase in apparent viscosity and the coefficient $k$, which is associated with an increase in the molar mass of pectin (Fracasso et al., 2018). The high molar mass of pectin promotes the formation of a gel structure (O'Donoghue and Somerfield, 2008). However, for some applications a lower viscosity may be seen as 
TABLE 1 | Parameters of the Ostwald-de Waele model describing the rheological properties of $1 \%$ strawberry pectin solutions.

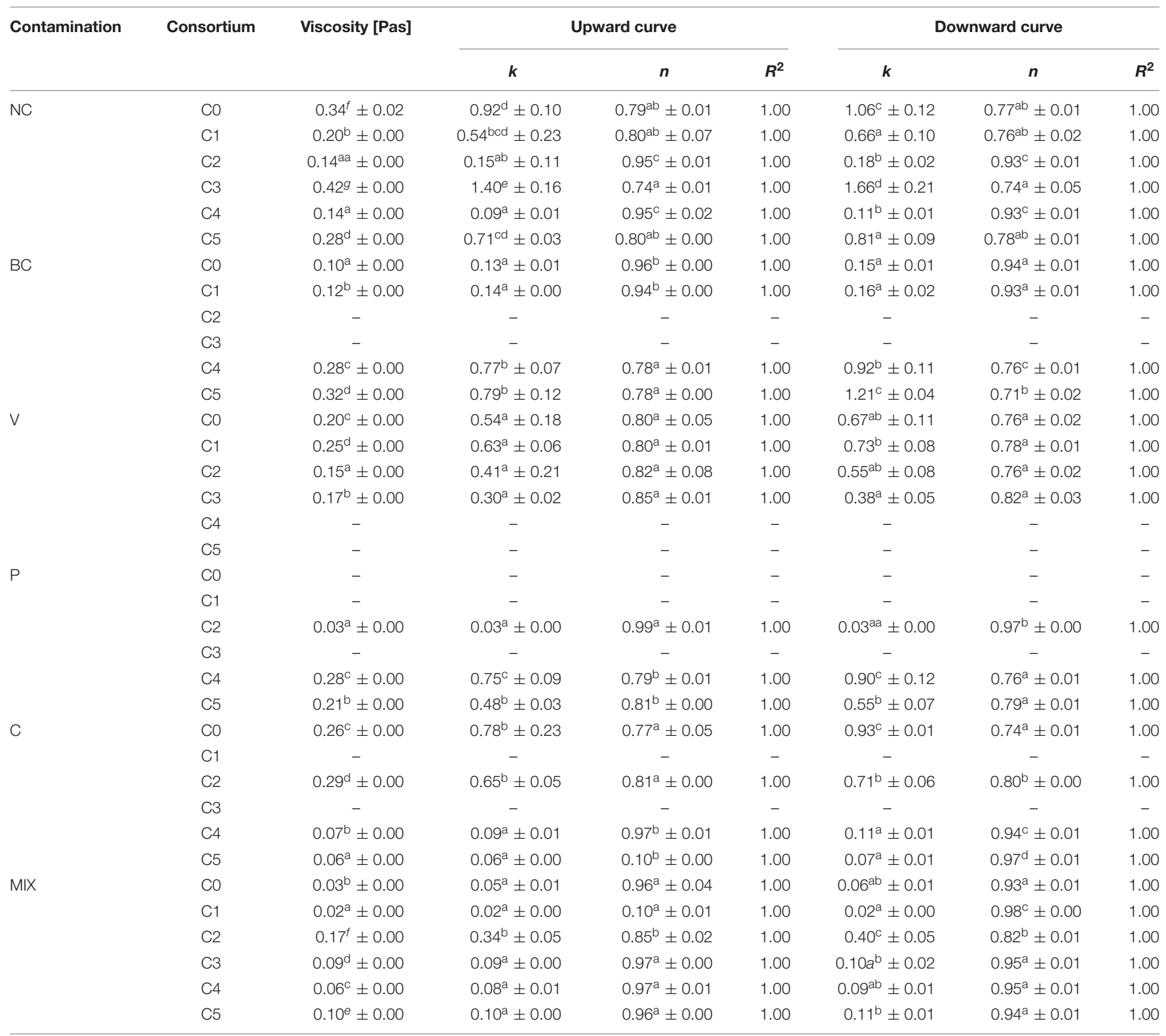

NC, control (no contamination); BC, B. cinerea; V, Verticillium sp.; P, Phytophthora sp.; C, Colletotrichum sp.; MIX, pathogen group (BC, V, P, and C); CO, control (no bacterial consortia); C1, Consortium 1; C2, Consortium 2; C3, Consortium 3; C4, Consortium 4; C5, Consortium 5. Different letters (a-f) indicate differences between experimental variants $(P<0.05)$ as determined by the Tukey HSD test. A statistical analysis was performed for each infected group of plants separately. Data are means $\pm S D(n=3)$.

a positive property of the solutions due to pelargonidine lower energy consumption during processing (Venzon et al., 2015).

Flow curves reveal pseudoplastic, non-Newtonian behaviour due to the melt flow index values $n(n<1)$. The $1 \%$ pectin solutions tested are classified as shear thinned. Their viscosity decreases as the shear rate increases. Based on a previous study, the lower the $n$ coefficient, the greater the degree of pseudoplasticity (Lee et al., 2009). The values of $n$ for the tested solutions were in the range of $0.713-0.996$. In comparison, the $n$ values for $2 \%$ strawberry pectin solutions were 0.52 , while for $5 \%$ strawberry pectin solutions they were
0.54 (Mierczyńska et al., 2017). Pseudoplastic fluid behaviour is important in the food industry (gelatinization of jellies and jams, thickening of juices and purees, and stabilization of liquids) (Grassino et al., 2016) and in medicine production (thickening of syrups or ointment, encapsulation of preparations) (Jouini et al., 2018).

The differences in the values of viscosity and in the flow of pectin solutions refers to the molecular properties of the samples, such as the chemical composition of neutral sugars, galacturonic acid content and the degree of pectin esterification (Fracasso et al., 2018). Microorganisms may have an indirect 
effect on the chemical composition of the samples (Erturk et al., 2012). The use of beneficial microorganisms such as Pseudomonas sp., Bacillus sp., and Azospirillum sp. results in an increase in plant biomass and fruit yields (Erturk et al., 2012). In addition, it was found that beneficial fungi and plant growth-promoting bacteria show antagonism to the pathogens C. acutatum, Macrophomina phaseolina, and Fusarium solani in strawberry plants (Pastrana et al., 2016). Inoculation with beneficial bacteria in order to increase plant growth also has potential environmental benefits; it could reduce the use of agricultural chemicals and facilitate adaptation to sustainable management practices (Erturk et al., 2012).

\section{Antagonistic Properties of Consortia Against Fungal Pathogens}

In Petri dish-based assays carried out for the determination of the antifungal properties of the tested bacterial consortia, C4 and C5 did not show any clear zone of inhibition in the growth of the tested fungi, and fungal-like-pathogens or only indicated very weak inhibition (Table 2). The inhibitory effect was observed for $\mathrm{C} 1, \mathrm{C} 2$, and $\mathrm{C} 3$, with evident growth inhibition of all of the tested fungal pathogens in the case of $\mathrm{C} 1$ and $\mathrm{C} 2$, thereby confirming the antagonistic properties of the bacterial strains present in these consortia, which was observed in a greenhouse experiment. Other studies are consistent with the obtained results and confirm the antagonism of the tested bacterial consortia (contained Bacillus sp., P. polymyxa, and Streptomyces sp.) against strawberry pathogenic microorganisms (Chen P.H. et al., 2018; Li et al., 2021).

\section{Influence of Microbial Activity on Soil Composition}

The content of nutrients, proteins, and soil enzyme activity plays a key role in the functioning of the ecosystem. The cultivation of plants is accompanied by a decrease in soil productivity related to the depletion of nutrients, the release of toxic metabolites, and the development of pathogenic fungi (Gałązka, 2013). Total glomalin (TG) is one of the glycoproteins produced by arbuscular mycorrhizal fungi that live in symbiosis with plants and facilitate the uptake of water and nutrients from the environment. Easily extractable glomalin (EEG) has a more immunoreactive fraction than TG (Wrigth and Upadhyaya, 1998). For this reason, an increase in TG and EEG levels is desirable in the context of promoting plant growth. An increase in the TG content as compared to the control ( $\mathrm{C} 0)$ was only observed in the strawberry NC (C5), while an increase in EEG content may be observed in the strawberry BC (C5) (Table 3).

The data shows the significant influence of the type of infectious pathogen and the bacterial consortium used on enzyme activity. The increase in acid phosphatase content as compared to the control $(\mathrm{C} 0)$ characterized the strawberry fruit in the groups $\mathrm{NC}(\mathrm{C} 3, \mathrm{C} 4$, and $\mathrm{C} 5), \mathrm{BC}(\mathrm{C} 2, \mathrm{C} 3$, and $\mathrm{C} 4), \mathrm{V}(\mathrm{C} 1, \mathrm{C} 2, \mathrm{C} 3$, and $\mathrm{C} 4)$, and $\mathrm{C}(\mathrm{C} 2, \mathrm{C} 3, \mathrm{C} 4$, and $\mathrm{C} 5)$, while an increase in the content of alkaline phosphatase occurred in groups $\mathrm{BC}(\mathrm{C} 1$ and C3), V (C3 and C4), P (C2, C3, C4, and C5), C (C4 and C5), and MIX (C2, C3, and C5) (Table 3). Increased phosphatase activity is associated with a higher content of organic matter in the soil (Singh et al., 2018). In contrast to phosphatase, a statistically significant increase in dehydrogenase content was observed in strawberry $\mathrm{V}(\mathrm{C} 1$ and $\mathrm{C} 3), \mathrm{C}(\mathrm{C} 1, \mathrm{C} 2, \mathrm{C} 3, \mathrm{C} 4$, and $\mathrm{C} 5)$, and MIX (C2, C4, and C5) (Table 3). The increase in dehydrogenase activity may be explained by the greater availability of nutrients (Kanchikerimath and Singh, 2001).

\section{Principal Component Analysis}

The relationships between the parameters studied were analysed using the PCA method (Figure 3). The distribution of individual samples on the plane is shown in Figures 3A,C,E,G,I,K. The first two factors (PC1 and PC2) explain over $50 \%$ of the total variance among the analysed samples for all of the investigated variables. For all of the tested samples, the first axis (PC1) accounted for over $30 \%$ of the total variance. The samples that explain the PC1 and PC2 axis positively have the greatest impact on the tested infection factor. On this basis, we may distinguish $\mathrm{C} 0$ and $\mathrm{C} 3$ for the NC control (Figure 3A), C0 for BC (Figure 3C), C0 for $\mathrm{V}$ (Figure 3E), C5 for P (Figure 3G), C2 for C (Figure 3I), and C3 for MIX (Figure 3K). An analysis of the PCA1-PCA2 observation charts (Figures $\mathbf{3 A}, \mathbf{C}, \mathbf{E}, \mathbf{G}, \mathbf{I}, \mathbf{K}$ ) confirms the results of the analyses above; the need to select an appropriate consortium which acts antagonistically against individual pathogens in order to obtain the highest quality of fruit.

An analysis of the PCA variable charts allowed for the identification of certain dependencies between the examined parameters in all of the studied groups, a positive correlation was found between DW and SSC, which was consistent with the results of other studies (Jorquera-Fontena et al., 2014). The increase in the content of anthocyanins (AC) was accompanied by an increase in the content of phenols (PC)

TABLE 2 | Antifungal properties of the bacterial consortia used in the test expressed as the inhibition zone diameter (mm).

Fungal pathogen/bacterial consortium

Colletotrichum sp. (C) G171/18
Phytophthora sp. (P) G408/18
Verticillium sp. (M) G296/18

Botrytis cinerea (B) G277/18
Inhibition zone $[\mathrm{mm}]$

\begin{tabular}{crrrr}
\hline C1 & \multicolumn{1}{c}{ C2 } & C3 & C4 & \multicolumn{1}{c}{ C5 } \\
\hline $37.3 \pm 2.5^{\mathrm{a}}$ & $37.6 \pm 2.0^{\mathrm{a}}$ & $15.3 \pm 1.5^{\mathrm{b}}$ & $0.0 \pm 0.0^{\mathrm{d}}$ & $6.3 \pm 0.6^{\mathrm{c}}$ \\
$56.0 \pm 1.0^{\mathrm{a}}$ & $57.6 \pm 2.0^{\mathrm{a}}$ & $48.6 \pm 1.5^{\mathrm{b}}$ & $0.0 \pm 0.0^{\mathrm{c}}$ & $0.0 \pm 0.0^{\mathrm{c}}$ \\
$40.6 \pm 6.0^{\mathrm{a}}$ & $6.6 \pm 0.5^{\mathrm{c}}$ & $15.3 \pm 0.6^{\mathrm{b}}$ & $0.0 \pm 0.0^{\mathrm{c}}$ & $14.3 \pm 1.1^{\mathrm{b}}$ \\
$42.0 \pm 6.0^{\mathrm{a}}$ & $39.6 \pm 7.6^{\mathrm{a}}$ & $12.6 \pm 2.1^{\mathrm{b}}$ & $11.7 \pm 3.0^{\mathrm{b}}$ & $6.3 \pm 0.6^{\mathrm{b}}$ \\
\hline
\end{tabular}

Different letters $(a-d)$ indicate differences between consortia $(P<0.05)$ as determined by the Tukey HSD test separately for each pathogen, \pm standard deviation; $C 1$, Consortium 1; C2, Consortium 2; C3, Consortium 3; C4, Consortium 4; C5, Consortium 5. 
TABLE 3 | Parameters of the quality of soil from strawberry cultivation.

\begin{tabular}{|c|c|c|c|c|c|c|c|c|}
\hline Contamination & Consortium & $\begin{array}{c}\text { Total } \\
\text { glomalin } \\
{\left[\mathrm{mg} \mathrm{g}^{-1}\right]}\end{array}$ & $\begin{array}{c}\text { Easily } \\
\text { extractable } \\
\text { glomalin } \\
{\left[\mathrm{mg} \mathrm{g}^{-1}\right]}\end{array}$ & $\begin{array}{c}\text { Dehydrogenase } \\
\text { activity }[\mu \mathrm{g} \mathrm{TPF} \mathrm{g} \\
\left.\text { DW of soil } 24 \mathrm{~h}^{-1}\right]\end{array}$ & $\begin{array}{l}\text { Acid phosphatase } \\
\text { activity [ } \mu \text { g PNP } \\
\mathrm{g}^{-1} \text { DW of soil } \mathrm{h}^{-1} \text { ] }\end{array}$ & $\begin{array}{c}\text { Alkaline } \\
\text { phosphatase } \\
\text { activity [ } \mu \mathrm{g} \text { PNP } \\
\mathrm{g}^{-1} \mathrm{DW} \text { of soil } \mathrm{h}^{-1} \text { ] }\end{array}$ & $\begin{array}{l}\text { Carbon in } \\
\text { biomass } \\
{\left[\mu \mathrm{g} \mathrm{g}^{-1}\right]}\end{array}$ & $\begin{array}{c}\text { Nitrogen in } \\
\text { biomass } \\
{\left[\mu \mathrm{g} \mathrm{g}^{-1}\right]}\end{array}$ \\
\hline \multirow[t]{6}{*}{ NC } & $\mathrm{CO}$ & $4.7^{a} \pm 0.6$ & $2.6^{a} \pm 0.1$ & $90.9^{a} \pm 2.1$ & $77.1^{\mathrm{a}} \pm 0.6$ & $77.5^{a b c} \pm 0.7$ & $330.0^{\mathrm{a}} \pm 14.4$ & $33.0^{\mathrm{ab}} \pm 1.2$ \\
\hline & $\mathrm{C} 1$ & $5.3^{a b} \pm 0.3$ & $2.9^{\mathrm{a}} \pm 0.2$ & $90.9^{a} \pm 2.8$ & $74.6^{\mathrm{a}} \pm 1.7$ & $75.5^{\mathrm{ab}} \pm 1.9$ & $376.9^{a} \pm 8.4$ & $34.7^{a b} \pm 0.4$ \\
\hline & $\mathrm{C} 2$ & $5.0^{a b} \pm 0.4$ & $3.0^{\mathrm{a}} \pm 0.3$ & $89.8^{a} \pm 2.6$ & $76.7^{\mathrm{a}} \pm 1.5$ & $84.5^{\mathrm{c}} \pm 2.7$ & $308.6^{a} \pm 50.3$ & $33.7^{a b} \pm 1.4$ \\
\hline & C3 & $5.0^{a b} \pm 0.3$ & $3.0^{\mathrm{a}} \pm 0.1$ & $92.5^{\mathrm{a}} \pm 3.2$ & $92.9^{b} \pm 0.5$ & $69.8^{a} \pm 3.1$ & $305.5^{\mathrm{a}} \pm 48.5$ & $32.4^{\mathrm{a}} \pm 1.4$ \\
\hline & $\mathrm{C} 4$ & $4.9^{a b} \pm 0.4$ & $3.0^{\mathrm{a}} \pm 0.0$ & $94.0^{\mathrm{a}} \pm 2.2$ & $93.5^{b} \pm 2.5$ & $71.8^{a b} \pm 2.6$ & $297.8^{a} \pm 46.8$ & $36.1^{b c} \pm 0.6$ \\
\hline & C5 & $6.0^{b} \pm 0.5$ & $3.0^{\mathrm{a}} \pm 0.2$ & $102.9^{a} \pm 3.7$ & $88.8^{c} \pm 0.5$ & $78.2^{b} \pm 4.3$ & $366.1^{\mathrm{a}} \pm 52.4$ & $39.0^{C} \pm 1.3$ \\
\hline \multirow[t]{6}{*}{$B C$} & $\mathrm{CO}$ & $5.6^{b} \pm 0.2$ & $2.7^{\mathrm{a}} \pm 0.1$ & $90.2^{\mathrm{C}} \pm 2.7$ & $79.7^{d} \pm 0.3$ & $67.2^{a b} \pm 5.4$ & $384.8^{a} \pm 18.8$ & $38.8^{a} \pm 2.3$ \\
\hline & $\mathrm{C} 1$ & $5.4^{a b} \pm 0.2$ & $2.9^{a b} \pm 0.2$ & $90.5^{c} \pm 3.6$ & $75.0^{c} \pm 1.6$ & $78.8^{c} \pm 1.7$ & $368.7^{a} \pm 44.7$ & $35.0^{\mathrm{b}} \pm 0.7$ \\
\hline & $\mathrm{C} 2$ & $4.7^{b} \pm 0.3$ & $2.9^{a b} \pm 0.3$ & $84.7^{\mathrm{bc}} \pm 1.9$ & $85.4^{\mathrm{a}} \pm 2.1$ & $65.0^{\mathrm{a}} \pm 2.7$ & $325.0^{a} \pm 7.2$ & $23.9^{c} \pm 0.9$ \\
\hline & C3 & $5.3^{a b} \pm 0.3$ & $3.1^{a b} \pm 0.1$ & $80.3^{a b} \pm 0.9$ & $88.9^{a b} \pm 0.9$ & $80.0^{c} \pm 2.8$ & $339.7^{a} \pm 26.2$ & $26.2^{c} \pm 0.6$ \\
\hline & $\mathrm{C} 4$ & $4.9^{a b} \pm 0.3$ & $3.0^{a b} \pm 0.1$ & $76.7^{\mathrm{a}} \pm 3.4$ & $93.0^{b} \pm 2.4$ & $74.5^{b c} \pm 2.0$ & $462.4^{b} \pm 3.9$ & $32.4^{b} \pm 0.2$ \\
\hline & C5 & $5.3^{a b} \pm 0.2$ & $3.1^{b} \pm 0.1$ & $78.9^{a b} \pm 1.0$ & $85.1^{a} \pm 0.6$ & $68.1^{\mathrm{ab}} \pm 3.7$ & $466.0^{b} \pm 14.6$ & $33.2^{b} \pm 0.8$ \\
\hline \multirow[t]{6}{*}{ V } & $\mathrm{CO}$ & $4.6^{a} \pm 0.2$ & $2.9^{a} \pm 0.0$ & $88.7^{\mathrm{ac}} \pm 2.2$ & $83.2^{\mathrm{a}} \pm 1.8$ & $63.1^{a} \pm 0.9$ & $481.5^{a} \pm 22.5$ & $33.1^{a} \pm 1.6$ \\
\hline & $\mathrm{C} 1$ & $5.1^{a} \pm 0.6$ & $3.1^{\mathrm{a}} \pm 0.1$ & $100.3^{b} \pm 1.6$ & $94.7^{b} \pm 2.0$ & $63.5^{\mathrm{a}} \pm 0.4$ & $503.6^{a} \pm 8.9$ & $37.8^{b} \pm 1.0$ \\
\hline & $\mathrm{C} 2$ & $4.8^{a} \pm 0.2$ & $3.1^{a} \pm 0.2$ & $98.1^{\mathrm{ab}} \pm 7.9$ & $94.4^{b} \pm 3.4$ & $61.9^{a} \pm 5.4$ & $511.6^{a} \pm 48.3$ & $37.7^{b} \pm 1.6$ \\
\hline & C3 & $5.0^{a} \pm 0.9$ & $3.2^{\mathrm{a}} \pm 0.2$ & $107.7^{b} \pm 2.1$ & $95.4^{b} \pm 1.9$ & $81.8^{c} \pm 2.8$ & $477.2^{a} \pm 10.6$ & $38.4^{b} \pm 1.2$ \\
\hline & $\mathrm{C} 4$ & $4.0^{a} \pm 0.2$ & $2.8^{a} \pm 0.1$ & $96.0^{\mathrm{ab}} \pm 0.9$ & $97.2^{b} \pm 1.8$ & $72.1^{d} \pm 1.4$ & $446.1^{a} \pm 55.4$ & $32.0^{\mathrm{a}} \pm 1.5$ \\
\hline & C5 & $5.3^{a} \pm 0.8$ & $2.9^{a} \pm 0.1$ & $82.6^{c} \pm 2.1$ & $85.9^{a} \pm 2.0$ & $66.6^{\mathrm{ad}} \pm 2.7$ & $448.9^{a} \pm 18.8$ & $22.5^{c} \pm 2.6$ \\
\hline \multirow[t]{6}{*}{ P } & $\mathrm{CO}$ & $5.2^{a} \pm 0.0$ & $2.8^{a} \pm 0.1$ & $94.4^{b} \pm 1.5$ & $91.7^{\mathrm{a}} \pm 1.2$ & $69.1^{b} \pm 1.6$ & $483.5^{\mathrm{ab}} \pm 28.0$ & $36.8^{a} \pm 1.7$ \\
\hline & C1 & $5.0^{a b} \pm 0.0$ & $2.8^{a} \pm 0.1$ & $82.3^{a} \pm 0.8$ & $89.3^{a} \pm 3.4$ & $65.5^{\mathrm{b}} \pm 1.2$ & $462.3^{a b} \pm 36.7$ & $34.5^{\mathrm{ab}} \pm 1.7$ \\
\hline & $\mathrm{C} 2$ & $4.6^{a b} \pm 0.1$ & $3.0^{\mathrm{a}} \pm 0.1$ & $86.0^{\mathrm{a}} \pm 2.4$ & $88.1^{a} \pm 0.5$ & $87.3^{c} \pm 2.9$ & $522.9^{b} \pm 15.6$ & $31.4^{b} \pm 1.5$ \\
\hline & C3 & $3.9^{b} \pm 0.3$ & $3.0^{\mathrm{a}} \pm 0.1$ & $86.8^{a} \pm 4.0$ & $95.4^{\mathrm{a}} \pm 5.0$ & $80.2^{a} \pm 2.3$ & $487.0^{a b} \pm 30.5$ & $32.1^{b} \pm 0.6$ \\
\hline & C4 & $4.9^{a b} \pm 0.8$ & $2.8^{a} \pm 0.1$ & $85.0^{\mathrm{a}} \pm 4.0$ & $93.1^{\mathrm{a}} \pm 2.6$ & $79.2^{a} \pm 0.4$ & $394.7^{\mathrm{ac}} \pm 46.0$ & $35.8^{a} \pm 1.1$ \\
\hline & C5 & $4.7^{a b} \pm 0.6$ & $2.7^{a} \pm 0.3$ & $89.6^{a b} \pm 2.5$ & $88.5^{\mathrm{a}} \pm 3.7$ & $78.6^{a} \pm 0.7$ & $333.0^{C} \pm 42.5$ & $36.0^{\mathrm{a}} \pm 0.4$ \\
\hline \multirow[t]{6}{*}{ C } & $\mathrm{CO}$ & $4.3^{a} \pm 0.8$ & $2.6^{a} \pm 0.1$ & $57.7^{\mathrm{c}} \pm 0.5$ & $71.8^{\mathrm{C}} \pm 2.6$ & $59.1^{a} \pm 0.4$ & $313.0^{\mathrm{a}} \pm 34.7$ & $33.7^{a} \pm 0.7$ \\
\hline & $\mathrm{C} 1$ & $3.8^{a} \pm 0.4$ & $2.6^{\mathrm{a}} \pm 0.2$ & $76.0^{\mathrm{ab}} \pm 1.8$ & $79.6^{\mathrm{ac}} \pm 1.3$ & $59.1^{a} \pm 0.3$ & $364.7^{\mathrm{ac}} \pm 13.4$ & $38.1^{b} \pm 0.8$ \\
\hline & $\mathrm{C} 2$ & $4.1^{a} \pm 0.4$ & $2.6^{a} \pm 0.1$ & $80.9^{b} \pm 1.9$ & $80.6^{a} \pm 3.7$ & $59.1^{\mathrm{a}} \pm 1.1$ & $394.5^{\mathrm{C}} \pm 15.3$ & $35.9^{a b} \pm 1.9$ \\
\hline & C3 & $4.8^{a} \pm 0.2$ & $2.5^{\mathrm{a}} \pm 0.2$ & $73.7^{\mathrm{a}} \pm 1.0$ & $86.2^{a b} \pm 1.3$ & $61.6^{a b} \pm 1.1$ & $455.4^{d} \pm 26.8$ & $36.7^{b} \pm 0.2$ \\
\hline & $\mathrm{C} 4$ & $4.4^{a} \pm 0.4$ & $2.6^{a} \pm 0.2$ & $101.6^{d} \pm 3.0$ & $90.1^{b} \pm 4.6$ & $62.9^{b} \pm 1.7$ & $362.7^{\mathrm{ac}} \pm 10.0$ & $36.5^{\mathrm{ab}} \pm 1.2$ \\
\hline & C5 & $3.9^{a} \pm 0.3$ & $2.3^{a} \pm 0.1$ & $78.1^{\mathrm{ab}} \pm 2.9$ & $93.9^{b} \pm 3.1$ & $70.2^{c} \pm 0.7$ & $309.7^{a} \pm 9.6$ & $35.9^{a b} \pm 0.7$ \\
\hline \multirow[t]{6}{*}{ MIX } & $\mathrm{CO}$ & $4.7^{\mathrm{ab}} \pm 0.1$ & $2.8^{a b} \pm 0.0$ & $74.1^{\mathrm{a}} \pm 3.3$ & $92.7^{b} \pm 5.5$ & $68.3^{a} \pm 0.9$ & $330.0^{a b} \pm 2.0$ & $36.4^{\mathrm{a}} \pm 1.4$ \\
\hline & C1 & $4.0^{a} \pm 0.3$ & $2.7^{a} \pm 0.0$ & $78.1^{a} \pm 2.3$ & $84.8^{a b} \pm 4.7$ & $58.5^{e} \pm 1.5$ & $323.2^{a b} \pm 12.5$ & $32.3^{b} \pm 0.9$ \\
\hline & $\mathrm{C} 2$ & $4.4^{a b} \pm 0.5$ & $2.9^{a b} \pm 0.1$ & $96.5^{b c} \pm 4.3$ & $86.4^{a b} \pm 4.2$ & $80.8^{d} \pm 2.7$ & $333.2^{a b} \pm 13.5$ & $36.0^{\mathrm{a}} \pm 0.4$ \\
\hline & C3 & $4.4^{a b} \pm 0.3$ & $3.0^{a b} \pm 0.1$ & $80.4^{a} \pm 0.8$ & $82.7^{\mathrm{ac}} \pm 0.6$ & $75.2^{\mathrm{bc}} \pm 1.0$ & $303.4^{a} \pm 13.1$ & $33.0^{\mathrm{b}} \pm 1.9$ \\
\hline & $\mathrm{C} 4$ & $5.0^{b} \pm 0.3$ & $3.1^{b} \pm 0.3$ & $95.4^{b} \pm 1.1$ & $88.1^{a b} \pm 1.6$ & $70.1^{a b} \pm 1.9$ & $347.4^{b} \pm 24.4$ & $38.0^{a} \pm 0.4$ \\
\hline & C5 & $4.6^{a b} \pm 0.3$ & $2.9^{a b} \pm 0.2$ & $102.7^{\mathrm{C}} \pm 1.7$ & $73.3^{c} \pm 1.6$ & $79.3^{\mathrm{cd}} \pm 2.9$ & $332.0^{a b} \pm 17.8$ & $31.4^{b} \pm 0.7$ \\
\hline
\end{tabular}

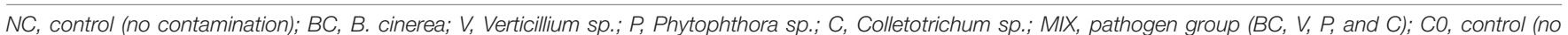

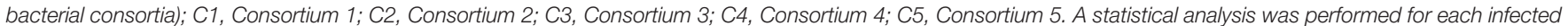

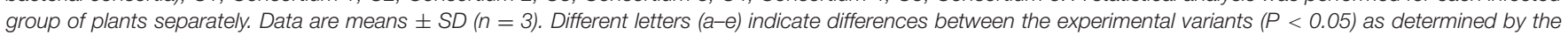

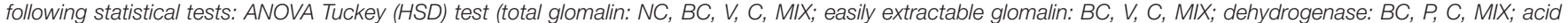

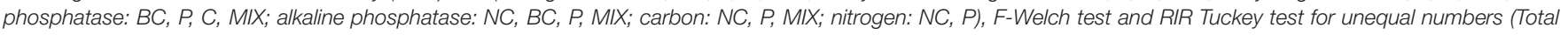

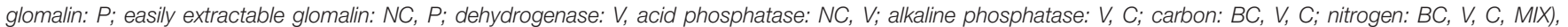
ANOVA Kruskal-Wallis test (dehydrogenase: NC).

only in strawberries infected with Phytophthora sp. (Figure $3 \mathbf{H}$ ). A positive correlation between the content of anthocyanins and polyphenols indicates a high antioxidant activity (Dembczyński et al., 2015). It was observed that an increase in total glomalin (TG) and easily extractable fractions of glomalin (EEG) in the soil were related to an increase in the level of nitrogen (NB) and carbon in biomass (CB) for the NC, V, and MIX groups (Figures 1B,F,L). Glomalin contains approximately 30\% of soil carbon and is the main component of soil organic matter (Gałązka, 2013), which is associated with a positive correlation between TG and EEG and CB. The growth of glomalin-producing bacteria (TG and EEG) requires a sufficiently high nitrogen concentration thereby explaining the positive correlation between TG, EEG, and NB (Gałązka, 2013). On the other hand, it is believed that an excessively high nitrogen level in the soil leads to a significant reduction in the activity of dehydrogenases involved in the transformation of soil 
carbon. High dehydrogenase activity provides favourable conditions for the development of microorganisms in the soil environment (Koper and Siwik-Ziomek, 2006). A positive correlation between dehydrogenase activity (DHA) and CB was noted for the uninfected samples and those infected by Verticillium sp., Colletotrichum sp. and a mixture of pathogens (Figures 1B,F,J,L), which is consistent with the results of the studies by Turski and Wyczółkowski (2008). Our research confirms that there is only a positive correlation between acid phosphatase and alkaline phosphatase for the group infected with Colletotrichum sp. (Figure 3J). For the remaining groups studied, there is either a negative or an absence of any correlation between these enzymes. This situation may be explained by the development of soil microorganisms limiting the activity of certain enzymes. It is assumed that an excess of inorganic phosphorus inhibits the synthesis of phosphatases (Nahas et al., 1982).

\section{CONCLUSION}

The interaction of beneficial bacteria and pathogenic fungi or fungal-like-pathogens makes it possible to preserve the high quality of strawberry fruit. The beneficial effects of the selected consortia were confirmed by comparing the results produced by infected strawberries with those of a positive control. On this basis, Consortium C2, which is composed of Bacillus sp. strains, was singled out as one of the most effective against selected pathogens in terms of maintaining the firmness of strawberries contaminated with a group of pathogens. There was an increase in strawberry firmness as compared to the positive control after the use of selected antifungal consortia. The microorganisms contained in the consortia also influenced an improvement in the biochemical properties of the strawberries, such as the soluble solids content and anthocyanins content. The application of consortia C2, C3, C4, and C5 was accompanied by an increase in the SSC in the fruit infected with Verticillium sp. as compared to the control, thereby improving the flavour of the strawberries. Consortium C5 significantly increased the level of anthocyanins in strawberries contaminated with Phytophthora sp. and B. cinerea, and in the control, it also increased the healthpromoting properties of the strawberries. The impact of the tested consortia on the pectin content of the strawberries was noted. In comparing the fruit samples with untreated beneficial microorganisms $(\mathrm{C} 0)$, it may be seen that the group of pathogens (MIX) reduced the content of D-galacturonic acid and thus pectin to the greatest extent. The following consortia: C2 (the control), C1 (B. cinerea), C2, C3, and C5 (Colletotrichum sp.)

\section{REFERENCES}

Agius, F., González-Lamothe, R., Caballero, J. L., Muñoz-Blanco, J., Botella, M. A., and Valpuesta, V. (2003). Engineering increased vitamin C levels in plants by overexpression of a D-galacturonic acid reductase. Nat. Biotechnol. 21, 177-181. doi: $10.1038 / \mathrm{nbt777}$

Ahmadi-Afzadi, M., Tahir, I., and Nybom, H. (2013). Impact of harvesting time and fruit firmness on the tolerance to fungal storage diseases in an apple germplasm and $\mathrm{C} 1$ (the pathogens group) may be identified as causing the highest increase in the content of extracted pectin in infected fruit as compared to Consortium $\mathrm{C} 0$. The decrease in viscosity was related to the increase in pectin content, which is indicated by the negative correlation between these values for the aforementioned groups (B. cinerea, Colletotrichum sp., pathogens group). For consortia C2 (control), C3 and C5 (Colletotrichum sp.) and C1 (pathogens group) the viscosity decreased by more than one and a half times as compared to Consortium $\mathrm{C} 0$.

Based on our research results, we may conclude that the tested consortia show a high degree of antagonism toward the tested fungus and allow for high-quality fruit to be obtained. The use of bacterial consortia also has the potential for reducing environmental pollution and the amount of fungicide residues in the fruit. However, more research is still required to identify the most effective consortia for combating strawberry and other soft fruit fungal diseases.

\section{DATA AVAILABILITY STATEMENT}

The original contributions presented in the study are included in the article, further inquiries can be directed to the corresponding author.

\section{AUTHOR CONTRIBUTIONS}

MD: writing - original draft, methodology, investigation, data curation, visualization, and formal analysis. JC: writing review and editing, conceptualization, methodology, resources, supervision, and data curation. AnG: writing - review and editing, methodology, investigation, resources, and data curation. BF-S: writing - review and editing, methodology, and resources. AM-G: methodology and investigation. LS-P: writing - review and editing, and resources. AgG: methodology, investigation, and data curation. PT: investigation. AZ: resources, supervision, and data curation. MF: writing - review and editing, conceptualization, resources, data curation, supervision, project administration, and funding acquisition. All authors contributed to the article and approved the submitted version.

\section{FUNDING}

This manuscript was financed by The National Centre for Research and Development within the framework of the BIOSTRATEG project, contract number BIOSTRATEG3/3444 33/16/NCBR/ 2018.

collection. Postharvest Biol. Technol. 82, 51-58. doi: 10.1016/j.postharvbio.2013. 03.001

Balci, G. (2021). Effects of melatonin applications on certain biochemical characteristics of strawberry seedlings in lime stress conditions. Turk. J. Agric. For. 45, 285-289. doi: 10.3906/tar-2006-83

Ben Abdallah, D., Frikha-Gargouri, O., and Tounsi, S. (2018). Rizhospheric competence, plant growth promotion and biocontrol efficacy of Bacillus amyloliquefaciens subsp. plantarum strain 
32a. Biol. Control 124, 61-67. doi: 10.1016/j.biocontrol.2018. 01.013

Berg, G., Kurze, S., Buchner, A., Wellington, E. M., and Smalla, K. (2000). Successful strategy for the selection of new strawberry-associated rhizobacteria antagonistic to Verticillium wilt. Can. J. Microbiol. 46, 1128-1137. doi: 10.1139/ w00-101

Cao, F., Guan, C., Dai, H., Li, X., and Zhang, Z. (2015). Soluble solids content is positively correlated with phosphorus content in ripening strawberry fruits. Sci. Hortic. 195, 183-187. doi: 10.1016/j.scienta.2015.09.018

Carmona-Hernandez, J. C., Taborda-Ocampo, G., and González-Correa, C. H. (2021). Folin-Ciocalteu reaction alternatives for higher polyphenol quantitation in colombian passion fruits. Int. J. Food Sci. 2021:8871301. doi: 10.1155/2021/ 8871301

Caulier, S., Gillis, A., Colau, G., Licciardi, F., Liépin, M., Desoignies, N., et al. (2018). Versatile antagonistic activities of soil-borne Bacillus spp. and Pseudomonas spp. against Phytophthora infestans and other potato pathogens. Front. Microbiol. 9, 1-15. doi: 10.3389/fmicb.2018.00143

Chan, S. Y., Choo, W. S., Young, D. J., and Loh, X. J. (2017). Pectin as a rheology modifier: Origin, structure, commercial production and rheology. Carbohydr. Polym. 161, 118-139. doi: 10.1016/j.carbpol.2016.12.033

Chen, H., Liu, Z., Cai, K., Xu, L., and Chen, A. (2018). Grid search parametric optimization for FT-NIR quantitative analysis of solid soluble content in strawberry samples. Vib. Spectrosc. 94, 7-15. doi: 10.1016/j.vibspec.2017. 10.006

Chen, P. H., Chen, R. Y., and Chou, J. Y. (2018). Screening and evaluation of yeast antagonists for biological control of B. cinerea on strawberry fruits. Mycobiology 46, 33-46. doi: 10.1080/12298093.2018.1454013

Cisternas-Jamet, J., Salvatierra-Martínez, R., Vega-Gálvez, A., Stoll, A., Uribe, E., and Goñi, M. G. (2020). Biochemical composition as a function of fruit maturity stage of bell pepper (Capsicum annum) inoculated with Bacillus amyloliquefaciens. Sci. Hortic. 263:109107. doi: 10.1016/j.scienta.2019.109107

Cota, L. V., Maffia, L. A., Mizubuti, E. S. G., and Macedo, P. E. F. (2009). Biological control by Clonostachys rosea as a key component in the integrated management of strawberry gray mold. Biol. Control 50, 222-230. doi: 10.1016/j.biocontrol. 2009.04.017

Crisosto, C. H., Crisosto, G. M., and Metheney, P. (2003). Consumer acceptance of 'Brooks' and 'Bing'cherries is mainly dependent on fruit SSC and visual skin color. Postharvest Biol. Technol. 28, 159-167. doi: 10.1016/S0925-5214(02) 00173-4

Cruz, A. F., Barka, G. D., Sylla, J., and Reineke, A. (2018). Biocontrol of strawberry fruit infected by Botrytis cinerea: Effects on the microbial communities on fruit assessed by next-generation sequencing. J. Phytopathol. 166, 403-411. doi: $10.1111 /$ jph. 12700

de Andrade, F. M., de Assis Pereira, T., Souza, T. P., Guimarães, P. H. S., Martins, A. D., Schwan, R. F., et al. (2019). Beneficial effects of inoculation of growthpromoting bacteria in strawberry. Microbiol. Res. 223-225, 120-128. doi: 10. 1016/j.micres.2019.04.005

Dembczyński, R., Białas, W., Olejnik, A., Kowalczewski, P., Drożdżyńska, A., and Jankowski, T. (2015). Acquisition of anthocyanins from chokeberry fruit, elderberry, blackcurrant and black carrot root by extraction method. Zywn. Nauk. Technol. Jakosc/Food. Sci. Technol. Qual. 22, 165-181. doi: 10.15193/zntj/ 2015/102/080

Døving, A., and Måge, F. (2002). Methods of testing strawberry fruit firmness. Acta Agricult. Scand. Sec. B-Plant Soil Sci. 52, 43-51. doi: 10.1080/ 090647102320260035

Erturk, Y., Ercisli, S., and Cakmakci, R. (2012). Yield and growth response of strawberry to plant growth-promoting Rhizobacteria inoculation. J. Plant Nutr. 35, 817-826. doi: 10.1080/01904167.2012.663437

European Biostimulants Industry Council (EBIC) (2021). https://biostimulants. $\mathrm{eu} /$.

European Commission (2019). The European Green Deal, Communication from the Commission to the European Parliament, the European Council, the Council, the European Economic and Social Committee and the Committee of the Regions. Brussels: European Commission.

Fan, Y., Xu, Y., Wang, D., Zhang, L., Sun, J., Sun, L., et al. (2009). Effect of alginate coating combined with yeast antagonist on strawberry (Fragaria $x$ ananassa) preservation quality. Postharvest Biol. Technol. 53, 84-90. doi: 10. 1016/j.postharvbio.2009.03.002
Folin, O., and Ciocalteu, V. (1927). On tyrosine and tryptophane determinations in proteins. J. Biol. Chem. 73, 50-627.

Fracasso, A. F., Perussello, C. A., Carpiné, D., Petkowicz, C. L., de, O., and Haminiuk, C. W. I. (2018). Chemical modification of citrus pectin: Structural, physical and rheological implications. Int. J. Biol. Macromol. 109, 784-792. doi: 10.1016/j.ijbiomac.2017.11.060

Fraeye, I., Knockaert, G., Buggenhout, S., Van, Duvetter, T., Hendrickx, M., et al. (2009). Enzyme infusion and thermal processing of strawberries: Pectin conversions related to firmness evolution. Food Chem. 114, 1371-1379. doi: 10.1016/j.foodchem.2008.11.041

Gałązka, A. (2013). Characteristics of glomalins and the influence of different cultivation systems on their content in soil. Polish J. Agron. 15, 75-82.

Grassino, A. N., Brnčić, M., Vikić-Topić, D., Roca, S., Dent, M., and Brnčić, S. R. (2016). Ultrasound assisted extraction and characterization of pectin from tomato waste. Food Chem. 198, 93-100. doi: 10.1016/j.foodchem.2015.11.095

Haggag, W. M., and Abo El Soud, M. (2012). Production and optimization of Pseudomonas fluorescens biomass and metabolites for biocontrol of strawberry grey mould. Am. J. Plant Sci. 3, 836-845. doi: 10.4236/ajps.2012.37101

Harker, F. R., Elgar, H. J., Watkins, C. B., Jackson, P. J., and Hallett, I. C. (2000). Physical and mechanical changes in strawberry fruit after high carbon dioxide treatments. Postharvest Biol. Technol. 19, 139-146. doi: 10.1016/S0925-5214(00) 00090-9

Harker, F. R., Gunson, F. A., and Jaeger, S. R. (2003). The case for fruit quality: an interpretive review of consumer attitudes, and preferences for apples. Postharvest Biol. Technol. 28, 333-347. doi: 10.1016/S0925-5214(02)00215-6

International Organization for Standardization (2000). Fruit and vegetable products - determination of dry matter content by drying under reduced pressure and of water content by azeotropic distillation. Geneva: International Organization for Standardization.

Ishikawa, T., Hayashi, A., Kyutoku, Y., Dan, I., Wada, T., Oku, K., et al. (2018). Classification of strawberry fruit shape by machine learning. Int. Arch. Photogramm. Remote Sens. Spat. Inf. Sci. XLII, 4-7. doi: 10.5194/isprsarchives-XLII-2-463-2018

Jensen, B., Knudsen, I. M. B., Andersen, B., Nielsen, K. F., Thrane, U., Jensen, D. F., et al. (2013). Characterization of microbial communities and fungal metabolites on field grown strawberries from organic and conventional production. Int. J. Food Microbiol. 160, 313-322. doi: 10.1016/j.ijfoodmicro.2012.11.005

Jin, P., Wang, H., Zhang, Y., Huang, Y., Wang, L., and Zheng, Y. (2017). UV$\mathrm{C}$ enhances resistance against gray mold decay caused by Botrytis cinerea in strawberry fruit. Sci. Hortic. 225, 106-111. doi: 10.1016/j.scienta.2017.06.062

Johnson, J., Collins, T., Walsh, K., and Naiker, M. (2020). Solvent extractions and spectrophotometric protocols for measuring the total anthocyanin, phenols and antioxidant content in plums. Chem. Papers 74, 4481-4492. doi: 10.1007/ s11696-020-01261-8

Jorquera-Fontena, E., Alberdi, M., and Franck, N. (2014). Pruning severity affects yield, fruit load and fruit and leaf traits of 'Brigitta' blueberry. J. Soil Sci. Plant Nutr. 14, 855-868. doi: 10.4067/s0718-95162014005000068

Jouini, M., Abdelhamid, A., Chaouch, M. A., Le Cerf, D., Bouraoui, A., Majdoub, H., et al. (2018). Physico-chemical characterization and pharmacological activities of polysaccharides from Opuntia microdasys var. rufida cladodes. Int. J. Biol. Macromol. 107, 1330-1338. doi: 10.1016/j.ijbiomac.2017.10.003

Juric, S., Vlahovicek-Kahlina, K., Duralija, B., Bandic, L. M., Nekic, P., and Vincekovic, M. (2021). Stimulation of plant secondary metabolites synthesis in soilless cultivated strawberries (Fragaria $x$ ananassa Duchesne) using zincalginate microparticles. Turk. J. Agric. For. 45, 324-334.

Kanchikerimath, M., and Singh, D. (2001). Soil organic matter and biological properties after 26 years of maize-wheat-cowpea cropping as affected by manure and fertilization in a Cambisol in semiarid region of India. Agric. Ecosyst. Environ. 86, 155-162. doi: 10.1016/S0167-8809(00)00280-2

Ke, J., Jiang, G., Shen, G., Wu, H., Liu, Y., and Zhang, Z. (2020). Optimization, characterization and rheological behavior study of pectin extracted from chayote (Sechium edule) using ultrasound assisted method. Int. J. Biol. Macromol. 147, 688-698. doi: 10.1016/j.ijbiomac.2020.01.055

Kim, Y. S., Lee, I. K., and Yun, B. S. (2015). Antagonistic effect of Streptomyces sp. BS062 against Botrytis diseases. Mycobiology 43, 339-342. doi: 10.5941/MYCO. 2015.43.3.339

Klein, D. A., Loh, T. C., and Goulding, R. L. (1964). Soil dehydrogenase activity. Soil Sci. 98, 371-376. doi: 10.1016/0038-0717(71)90049-6 
Koper, J., and Siwik-Ziomek, A. (2006). Effect of long-term fertilization on the activity of dehydrogenases in soil and the content of organic carbon and total nitrogen. Zesz. Probl. Postêpów Nauk Rol. 1, 197-202.

Koubala, B. B., Mbome, L. I., Kansci, G., Mbiapo, F. T., and Crepeau, M. (2008). Physicochemical properties of pectins from ambarella peels (Spondias cytherea) obtained using different extraction conditions. Food Chem. 106, 1202-1207. doi: 10.1016/j.foodchem.2007.07.065

Kovačević, D. B., Putnik, P., Dragović-Uzelac, V., Vahčić, N., Babojelić, M. S., and Levaj, B. (2015). Influences of organically and conventionally grown strawberry cultivars on anthocyanins content and color in purees and low-sugar jams. Food Chem. 181, 94-100.

Krimm, U., Abanda-Nkpwatt, D., Schwab, W., and Schreiber, L. (2005). Epiphytic microorganisms on strawberry plants (Fragaria ananassa cv. Elsanta): Identification of bacterial isolates and analysis of their interaction with leaf surfaces. FEMS Microbiol. Ecol. 53, 483-492. doi: 10.1016/j.femsec.2005. 02.004

Landum, M. C., Félix, M., do, R., Alho, J., Garcia, R., Cabrita, M. J., et al. (2016). Antagonistic activity of fungi of Olea europaea L. against Colletotrichum acutatum. Microbiol. Res. 183, 100-108. doi: 10.1016/j.micres.2015.12.001

Lazazzara, V., Perazzolli, M., Pertot, I., Biasioli, F., Puopolo, G., and Cappellin, L. (2017). Growth media affect the volatilome and antimicrobial activity against Phytophthora infestans in four Lysobacter type strains. Microbiol. Res. 201, 52-62. doi: 10.1016/j.micres.2017.04.015

Lee, C. H., Moturi, V., and Lee, Y. (2009). Thixotropic property in pharmaceutical formulations. J. Control. Release 136, 88-98. doi: 10.1016/j.jconrel.2009. 02.013

Li, X., Jing, T., Zhou, D., Zhang, M., Qi, D., Zang, X., et al. (2021). Biocontrol efficacy and possible mechanism of Streptomyces sp. H4 against postharvest anthracnose caused by Colletotrichum fragariae on strawberry fruit. Postharv. Biol. Tech. 175:111401. doi: 10.1016/j.postharvbio.2020.111401

Lima, N. B., Marcus, M. V., De Morais, M. A., Barbosa, M. A. G., Michereff, S. J., Hyde, K. D., et al. (2013). Five Colletotrichum species are responsible for mango anthracnose in northeastern Brazil. Fungal Divers 61, 75-88. doi: 10.1007/s13225-013-0237-6

Lingua, G., Bona, E., Manassero, P., Marsano, F., Todeschini, V., Cantamessa, S., et al. (2013). Arbuscular mycorrhizal fungi and plant growth-promoting Pseudomonads increases anthocyanin concentration in strawberry fruits (Fragaria x ananassa var. Selva) in conditions of reduced fertilization. Int. J. Mol. Sci. 14, 16207-16225. doi: 10.3390/ijms140816207

Liu, B., Wang, K., Shu, X., Liang, J., Fan, X., and Sun, L. (2019). Changes in fruit firmness, quality traits and cell wall constituents of two highbush blueberries (Vaccinium corymbosum L.) during postharvest cold storage. Sci. Hortic. 246, 557-562. doi: 10.1016/j.scienta.2018.11.042

López-Ortiz, A. L. L., Méndez, L., Cornelio, D., Adriana, L., and Jorge, E. J. M. (2019). Understanding the drying kinetics of phenolic compounds in strawberries: An experimental and density functional theory study. Innov. Food Sci. Emerg. Technol. 60:102283. doi: 10.1016/j.ifset.2019.102

Mackenzie, S. J., Chandler, C. K., Hasing, T., and Whitaker, V. M. (2011). The role of temperature in the late-season decline in soluble solids content of strawberry fruit in a subtropical production system. Hort Sci. 46, 1562-1566.

Magwaza, L. S., and Opara, U. L. (2015). Analytical methods for determination of sugars and sweetness of horticultural products-A review. Sci. Hortic. 184, 179-192. doi: 10.1016/j.scienta.2015.01.001

Makarova, E. N., and Shakhmatov, E. G. (2020). Structural characteristics of oxalate-soluble polysaccharides from Norway spruce (Picea abies) foliage. Carbohydr. Poly. 246:116544. doi: 10.1016/j.carbpol.2020.116544

Malarczyk, D. G., Panek, J., and Frąc, M. (2020). Triplex Real Time PCR approach for the detection of crucial fungal berry pathogens-Botrytis spp., Colletotrichum spp. and Verticillium spp. Int. J. Mol. Sci. 21, 1-17. doi: 10.3390/ijms21228469

Mierczyńska, J., Cybulska, J., Pieczywek, P. M., and Zdunek, A. (2014). Effect of storage on rheology of water-soluble, chelate-soluble and diluted alkali-soluble pectin in carrot cell walls. Food Bioprocess Technol. 8, 171-180. doi: 10.1007/ s11947-014-1392-9

Mierczyńska, J., Cybulska, J., and Zdunek, A. (2017). Rheological and chemical properties of pectin enriched fractions from different sources extracted with citric acid. Carbohydr. Polym. 156, 443-451. doi: 10.1016/j.carbpol.2016.09.042

Milijasevic-Marcic, S., Todorovic, V., Stanojevic, O., Beric, T., Stankovic, S., Todorovic, B., et al. (2018). Antagonistic potential of Bacillus spp. isolates against bacterial pathogens of tomato and fungal pathogen of pepper. J. Pestic. Phytomedicine 33, 9-18. doi: 10.2298/pif1801009m

Miller, W. R., McDonald, R. E., and Chaparro, J. (2000). Tolerance of selected orange and mandarin hybrid fruit to low-dose irradiation for quarantine purposes. HortScience 35, 1288-1291. doi: 10.21273/HORTSCI.35.7.1288

Min, B., Lim, J., Ko, S., Lee, K., Ho, S., and Lee, S. (2011). Environmentally friendly preparation of pectins from agricultural by products and their structural/rheological characterization. Bioresour. Technol. 102, 3855-3860. doi: 10.1016/j.biortech.2010.12.019

Moreira, R. R., Nesi, C. N., May, and De Mio, L. L. (2014). Bacillus spp. and pseudomonas putida as inhibitors of the Colletotrichum acutatum group and potential to control glomerella leaf spot. Biol. Control 72, 30-37. doi: 10.1016/j. biocontrol.2014.02.001

Nahas, E., Ternezi, H. F., and Rossi, A. (1982). Effect of carbon source and pH on the production and secretion of acid phosphatase and alkaline phosphatase in Neurospora crassa. J. Gen. Microbiol. 128, 2017-2021.

Nguyen, X. H., Naing, K. W., Lee, Y. S., Kim, Y. H., Moon, J. H., and Kim, K. Y. (2015). Antagonism of antifungal metabolites from Streptomyces griseus $\mathrm{H} 7602$ against Phytophthora capsici. J. Basic Microbiol. 55, 45-53. doi: 10.1002/jobm. 201300820

Nunes, C. M. N., Brecht, J. K., Morais, A. M. M. B., and Sargent, S. A. (2001). Possible influences of water loss and polyphenol oxidase activity on anthocyanin content and discoloration in fresh ripe strawberry (cv . Oso Grande) during storage at $1^{\circ}$ C. J. Food Sci. 70, 79-84. doi: 10.1111/j.1365-2621. 2005.tb09069.x

O'Donoghue, E. M., and Somerfield, S. D. (2008). Biochemical and rheological properties of gelling pectic isolates from buttercup squash fruit. Food Hydrocoll. 22, 1326-1336. doi: 10.1016/j.foodhyd.2007.07.002

Ognyanov, M., Remoroza, C. A., Schols, H. A., Petkova, N. T., and Georgiev, Y. N. (2021). Structural study of a pectic polysaccharide fraction isolated from "mountain tea"(Sideritis scardica Griseb.). Carbohydr. Poly. 260:117798. doi: 10.1016/j.carbpol.2021.117798

Olanrewaju, O. S., and Babalola, O. O. (2019). Streptomyces: implications and interactions in plant growth promotion. Appl. Microbiol. Biotechnol. 103, 11791188. doi: 10.1007/s00253-018-09577-y

Ornelas-Paz, J. D. J., Yahia, E. M., Ramírez-Bustamante, N., Pérez-Martínez, J. D., Escalante-Minakata, M. D. P., Ibarra-Junquera, V., et al. (2013). Physical attributes and chemical composition of organic strawberry fruit (Fragaria $x$ ananassa Duch, Cv. Albion) at six stages of ripening. Food Chem. 138, 372-381. doi: 10.1016/j.foodchem.2012.11.006

Oszust, K., Cybulska, J., and Frąc, M. (2020). How do Trichoderma genus fungi win a nutritional competition battle against soft fruit pathogens? A report on niche overlap nutritional potentiates. Int. J. Mol. Sci. 21, 1-19. doi: 10.3390/ ijms 21124235

Ozdemir, F., and Topuz, A. (2004). Changes in dry matter, oil content and fatty acids composition of avocado during harvesting time and post-harvesting ripening period. Food Chem. 86, 79-83. doi: 10.1016/j.foodchem.2003. 08.012

Paniagua, C., Santiago-Doménech, N., Kirby, A. R., Gunning, A. P., Morris, V. J., Quesada, M. A., et al. (2017). Structural changes in cell wall pectins during strawberry fruit development. Plant Physiol. Biochem. 118, 55-63. doi: 10.1016/ j.plaphy.2017.06.001

Pastrana, A. M., Basallote-Ureba, M. J., Aguado, A., Akdi, K., and Capote, N. (2016). Biological control of strawberry soil-borne pathogens Macrophomina phaseolina and Fusarium solani, using Trichoderma asperellum and Bacillus spp. Phytopathol. Mediterr. 55, 109-120. doi: 10.14601/Phytopathol

Ponder, A., and Hallmann, E. (2019). The effects of organic and conventional farm management and harvest time on the polyphenol content in different raspberry cultivars. Food Chem. 301:125295. doi: 10.1016/j.foodchem.2019.125295

Poveda, J. (2020). Use of plant-defense hormones against pathogen-diseases of postharvest fresh produce. Physiol. Mol. Plant Pathol. 111:101521. doi: 10.1016/ j.pmpp.2020.101521

Poveda, J., Barquero, M., and González-Andrés, F. (2020). Insight into the microbiological control strategies against B. cinerea using systemic plant resistance activation. Agronomy 10:1822. doi: 10.3390/agronomy10111822

Qin, X., Xiao, H., Cheng, X., Zhou, H., and Si, L. (2017). Hanseniaspora uvarum prolongs shelf life of strawberry via volatile production. Food Microbiol. 63, 205-212. doi: 10.1016/j.fm.2016.11.005 
Reyes-Yanes, A., Martinez, P., and Ahmad, R. (2020). Real-time growth rate and fresh weight estimation for little gem romaine lettuce in aquaponic grow beds. Comp. Electr. Agricult. 179:105827. doi: 10.1016/j.compag.2020.105827

Rey-Serra, P., Mnejja, M., and Monfort, A. (2021). Shape, firmness and fruit quality QTLs shared in two non-related strawberry populations. Plant Sci. 11:111010. doi: 10.1016/j.plantsci.2021.111010

Santiago, R., Huiliñir, C., Cottet, L., and Castillo, A. (2016). Microbiological characterization for a new wild strain of Paenibacillus polymyxa with antifungal activity against Botrytis cinerea. Biol. Control 103, 251-260. doi: 10.1016/j. biocontrol.2016.10.002

Siebeneichler, T. J., Crizel, R. L., Camozatto, G. H., Paim, B. T., da Silva, Messias, R., et al. (2020). The postharvest ripening of strawberry fruits induced by abscisic acid and sucrose differs from their in vivo ripening. Food Chem. 317, 126-407. doi: 10.1016/j.foodchem.2020.126407

Singh, G., Bhattacharyya, R., Das, T. K., Sharma, A. R., Ghosh, A., Das, S., et al. (2018). Crop rotation and residue management effects on soil enzyme activities, glomalin and aggregate stability under zero tillage in the Indo-Gangetic Plains. Soil. Tillage Res. 184, 291-300. doi: 10.1016/j.still.2018.08.006

Sowik, I., Bielenin, A., and Michalczuk, L. (2001). In vitro testing of strawberry resistance to Verticillium dahliae and Phytophthora cactorum. Sci. Hortic. 88, 31-40. doi: 10.1016/S0304-4238(00)00195-3

Srivastava, R., Tripathi, B. M., Singh, R. K., Srivastva, P., Kumari, P., Srivastav, M., et al. (2011). Profiling of plant growth promoting bacteria associated with Jaunpuri giant radish rhizosphere. Int. J. Agric. Biol. 13, 9-17.

Tabatabai, M. A., and Bremner, J. M. (1969). Use of p-nitrophenyl phosphate for assay of soil phosphatase activity. Soil Biol. Biochem. 1, 301-307. doi: 10.1016/ 0038-0717(69)90012-1

Tang, B., Laborda, P., Sun, C., Xu, G., Zhao, Y., and Liu, F. (2019). Improving the production of a novel antifungal alteramide $\mathrm{B}$ in Lysobacter enzymogenes $\mathrm{OH} 11$ by strengthening metabolic flux and precursor supply. Bioresour. Technol. 273, 196-202. doi: 10.1016/j.biortech.2018.10.085

Tarantino, A., Lops, F., Disciglio, G., and Lopriore, G. (2018). Effects of plant biostimulants on fruit set, growth, yield and fruit quality attributes of 'Orange rubis ${ }^{\circledR}$ ' apricot (Prunus armeniaca L.) cultivar in two consecutive years. Sci. Hortic. 239, 26-34. doi: 10.1016/j.scienta.2018.04.055

Todeschini, V., Aitlahmidi, N., Mazzucco, E., Marsano, F., Gosetti, F., Robotti, E., et al. (2018). Impact of beneficial microorganisms on strawberry growth, fruit production, nutritional quality, and volatilome. Front. Plant Sci. 9, 1-22. doi: $10.3389 /$ fpls.2018.01611

Tomic, J. M., Milivojevic, J. M., and Pesakovic, M. I. (2015). The response to bacterial inoculation is cultivar-related in strawberries. Turkish J. Agric. For. 39, 332-341. doi: 10.3906/tar-1410-16

Tournas, V. H., and Katsoudas, E. (2005). Mould and yeast flora in fresh berries, grapes and citrus fruits. Int. J. Food Microbiol. 105, 11-17. doi: 10.1016/j. ijfoodmicro.2005.05.002

Turski, M., and Wyczółkowski, A. (2008). Influence of diversified use of soils from loess on respiration activity of dehydrogenases. Acta Agrophysica 12, 801-811.

Valentinuzzi, F., Mason, M., Scampicchio, M., Andreotti, C., Cesco, S., and Mimmo, T. (2015). Enhancement of the bioactive compound content in strawberry fruits grown under iron and phosphorus deficiency. J. Sci. Food Agric. 95, 2088-2094. doi: 10.1002/jsfa.6924
Venzon, S. S., Canteri, M. H. G., Granato, D., Demczuk, B., Maciel, G. M., Stafussa, A. P., et al. (2015). Physicochemical properties of modified citrus pectins extracted from orange pomace. J. Food Sci. Technol. 52, 4102-4112. doi: 10.1007/s13197-014-1419-2

Wang, W., Zhong, Z., Wang, Q., Wang, H., Fu, Y., and He, X. (2017). Glomalin contributed more to carbon, nutrients in deeper soils, and differently associated with climates and soil properties in vertical profiles. Sci. Rep. 7, 1-13. doi: 10.1038/s41598-017-12731-7

Wilcox, W. F., Scott, P. H., Hamm, P. B., Kennedy, D. M., Duncan, J. M., Brasier, C. M., et al. (1993). Identity of a Phytophthora species attacking raspberry in Europe and North America. Mycol. Res. 97, 817-831. doi: 10.1016/S09537562(09)81157-X

Win, T. T., Bo, B., Malec, P., and Fu, P. (2021). The effect of a consortium of Penicillium sp. and Bacillus spp. in suppressing banana fungal diseases caused by Fusarium sp. and Alternaria sp. J. Appl. Microbiol. 2021:15067. doi: 10.1111/ jam. 15067

Wrigth, S. F., and Upadhyaya, A. (1998). A survey of soils for aggregate stability and glomalin, a glycoprotein produced by hyphae of arbuscular mycorrhizal fungi. Plant Soil 198, 97-107.

Xie, F., Wang, Z., and Liu, J. (2021). Effects of pectins with different structural and conformational characteristics on gelatinization and retrogradation of corn starch. Starch-Stärke 73:2100094. doi: 10.1002/star.202100094

Yagmur, B., and Gunes, A. (2021). Evaluation of the effects of plant growth promoting rhizobacteria (pgpr) on yield and quality parameters of tomato plants in organic agriculture by principal component analysis (PCA). Gesunde Pflanzen 73, 219-228. doi: 10.1007/s10343-021-00543-9

Zahedipour-Sheshglani, P., and Asghari, M. (2020). Impact of foliar spray with 24-epibrassinolide on yield, quality, ripening physiology and productivity of the strawberry. Sci. Hortic. 268, 109-376. doi: 10.1016/j.scienta.2020. 109376

Zhang, F., Li, X. L., Zhu, S. J., Ojaghian, M. R., and Zhang, J. Z. (2018). Biocontrol potential of Paenibacillus polymyxa against Verticillium dahliae infecting cotton plants. Biol. Control 127, 70-77. doi: 10.1016/j.biocontrol.2018.08.021

Conflict of Interest: The authors declare that the research was conducted in the absence of any commercial or financial relationships that could be construed as a potential conflict of interest.

Publisher's Note: All claims expressed in this article are solely those of the authors and do not necessarily represent those of their affiliated organizations, or those of the publisher, the editors and the reviewers. Any product that may be evaluated in this article, or claim that may be made by its manufacturer, is not guaranteed or endorsed by the publisher.

Copyright (C) 2021 Drobek, Cybulska, Gałazka, Feledyn-Szewczyk, Marzec-Grzadziel, Sas-Paszt, Gryta, Trzcinski, Zdunek and Frac. This is an open-access article distributed under the terms of the Creative Commons Attribution License (CC BY). The use, distribution or reproduction in other forums is permitted, provided the original author(s) and the copyright owner(s) are credited and that the original publication in this journal is cited, in accordance with accepted academic practice. No use, distribution or reproduction is permitted which does not comply with these terms. 